\title{
New genetic findings in a large cohort of congenital hypogonadotropic hypogonadism
}

\author{
Lorena Guimaraes Lima Amato', Luciana Ribeiro Montenegro', Antonio Marcondes Lerario, ${ }^{1,2}$, \\ Alexander Augusto Lima Jorge ${ }^{3}$, Gil Guerra Junior ${ }^{4}$, Caroline Schnoll', Alessandra Covallero Renck', \\ Ericka Barbosa Trarbach ${ }^{3}$, Elaine Maria Frade Costa', Berenice Bilharinho Mendonca', Ana Claudia Latronico ${ }^{1}$ \\ and Leticia Ferreira Gontijo Silveira ${ }^{1,5}$
}

\begin{abstract}
'Unidade de Endocrinologia do Desenvolvimento, Laboratório de Hormônios e Genética Molecular/LIM42, Disciplina de Endocrinologia e Metabologia, Hospital das Clinicas da Faculdade de Medicina da Universidade de São Paulo, São Paulo, São Paulo, Brasil, ${ }^{2}$ Division of Metabolism, Endocrinology and Diabetes, Department of Internal Medicine, University of Michigan, Ann Arbor, Michigan, USA, ${ }^{3}$ Unidade de Endocrinologia Genetica/LIM25, Disciplina de Endocrinologia e Metabologia, Hospital das Clinicas da Faculdade de Medicina da Universidade de São Paulo, São Paulo, São Paulo, Brasil, ${ }^{4}$ Departamento de Pediatria, Faculdade de Ciências Médicas da Universidade Estadual de Campinas (UNICAMP), Campinas, São Paulo, Brasil, and ${ }^{5}$ Departamento de Clínica Médica, Faculdade de Medicina da Universidade Federal de Minas Gerais, Belo Horizonte, Minas Gerais, Brasil
\end{abstract}

Correspondence should be addressed to A C Latronico or L F G Silveira Email anaclusp@gmail.com or leticiafgs@gmail.com

\begin{abstract}
Context: Congenital hypogonadotropic hypogonadism $(\mathrm{CHH})$ is a rare condition caused by $\mathrm{GnRH}$ deficiency. Several genes have been associated with the pathogenesis of $\mathrm{CHH}$, but most cases still remain without a molecular diagnosis. The advent of next-generation sequencing (NGS) has allowed the simultaneous genotyping of several regions, faster, making possible the extension of the genetic knowledge of $\mathrm{CHH}$.

Objective: Genetic characterization of a large cohort of Brazilian $\mathrm{CHH}$ patients.

Design and patients: A cohort of 130 unrelated patients (91 males, 39 females) with CHH (75 normosmic CHH, 55 Kallmann syndrome) was studied using a panel containing $36 \mathrm{CHH}$-associated genes.

Results: Potential pathogenic or probably pathogenic variants were identified in 43 (33\%) CHH patients. The genes ANOS1, FGFR1 and GNRHR were the most frequently affected. A novel homozygous splice site mutation was identified in the GNRH1 gene and a deletion of the entire coding sequence was identified in SOX10. Deleterious variants in the IGSF10 gene were identified in two patients with reversible normosmic $\mathrm{CHH}$. Notably, $6.9 \%$ of the patients had rare variants in more than one gene. Rare variants were also identified in SPRY4, IL17RD, FGF17, IGSF1 and FLRT3 genes. Conclusions: This is a large study of the molecular genetics of $\mathrm{CHH}$ providing new genetic findings for this complex and heterogeneous genetic condition. NGS has been shown to be a fast, reliable and effective tool in the molecular diagnosis of congenital $\mathrm{CHH}$ and being able to targeting clinical genetic testing in the future.
\end{abstract}

\section{Introduction}

Normal pubertal development is dependent on the secretion and proper action of the gonadotropin-releasing hormone $(\mathrm{GnRH})$, produced by a small number of neurons located in the ventromedial hypothalamus (1, 2). GnRH-secreting neurons have their origin outside the central nervous system (CNS), in the olfactory placode, and migrate in association with olfactory neurons during the embryonic life to their final hypothalamic location $(1,2,3)$. Congenital hypogonadotropic hypogonadism $(\mathrm{CHH})$ is a rare condition caused by GnRH deficiency, clinically manifested as sexual infantilism, low serum steroid concentrations associated to low or normal
(C) 2019 European Society of Endocrinology Printed in Great Britain
Published by Bioscientifica Ltd. 
levels of gonadotropins, and otherwise normal pituitary functions. Because of the common embryonic origin of olfactory and GnRH neurons, $\mathrm{CHH}$ is often associated with olfactory defects, characterizing Kallmann syndrome (KS), which corresponds to approximately $50-60 \%$ of $\mathrm{CHH}$ cases (3).

$\mathrm{CHH}$ is a clinical and genetically heterogeneous condition. In the last decades, a growing list of genes has been implicated in the molecular pathogenesis of $\mathrm{CHH}$. These genes are involved in different stages of the regulation of GnRH production, secretion or action, as well as in the process of embryonic neuronal migration $(3,4,5)$. Some of these genes have been classically known to cause $\mathrm{CHH}$, such as ANOS1 (previously termed KAL1), which is associated with the X-linked form of KS, with a severe reproductive phenotype, whereas GNRHR mutations are a common cause of autosomal recessive normosmic $\mathrm{CHH}(\mathrm{nCHH})(3,6,7$, $8,9,10)$. On the other hand, mutations in genes such as FGFR1, FGF8, PROK2 and PROKR2 have been associated with substantial intra and interfamilial phenotypic variability, with affected members presenting with KS, $\mathrm{nCHH}$, isolated anosmia, isolated lip-palatine cleft, constitutional delay of growth and puberty (CDGP) or even normal phenotype $(5,8,11,12)$. In addition, the advancement of genetic screening techniques allowed the identification of variants in more than one gene in the same patient, changing the previous concept of $\mathrm{CHH}$ as a strictly monogenic disease (13, 14, 15). Currently, more than 30 genes have been associated with syndromic and non-syndromic forms of $\mathrm{CHH}(3,4,5)$. However, despite the vast history of the genetic causes of $\mathrm{CHH}$, until recently only about $30 \%$ of these patients had a recognized molecular diagnosis (4).

In the last two decades, we have been studying the genetic causes of GnRH deficiency by screening CHHassociated genes, including ANOS1, GNRHR, FGFR1, FGF8, PROKR2, PROK2, TACR3, TAC3, KISS1R and KISS1 using classical genetic methods, such as Sanger sequencing and multiplex ligation-dependent probe amplification $(9,10,16,17,18,19,20,21,22,23)$. Nevertheless, the majority of the patients remain undiagnosed from the molecular point of view. With the growing number of genes and the genetic complexity of $\mathrm{CHH}$, it has become almost impossible to keep the screening of all candidate genes updated using the traditional techniques. The recent advent of next-generation sequencing (NGS) has allowed the screening of a large numbers of genes quickly and efficiently.

\section{Patients and methods}

\section{Patients}

Patients were selected from the outpatient clinic of the Developmental Endocrinology Unit, Hospital das Clínicas da Faculdade de Medicina, Universidade de São Paulo (HCFMUSP) and from the Hospital das Clínicas da Universidade de Campinas (Unicamp). The project was approved by the Ethics Committee of Sao Paulo University. All patients or their caregivers signed the informed consent form for participation in the research.

A total of 130 unrelated Brazilian patients with $\mathrm{CHH}$ (75 nCHH and $55 \mathrm{KS}$, including 91 men and 39 women) was studied by targeted NGS. The clinical criteria for inclusion of the patients were lack of appearance or incomplete development of secondary sexual characteristics after 16 years of age in girls and 18 years of age in boys; subnormal concentrations of sexual steroids (testosterone or estradiol), subnormal or normal luteinizing hormone (LH) and follicle-stimulating hormone (FSH) concentrations, absence of other associated pituitary deficiencies and normal imaging of CNS. The University of Pennsylvania Smell Identification Test was used to diagnose olfactory abnormalities (Smell Identification Test, Philadelphia, PA, USA) (24). Additional phenotypic abnormalities were observed in some patients as follows: congenital hearing impairment (4.6\%), cognitive deficit (3.8\%), epilepsy $(2.3 \%)$, heart defects $(1.5 \%)$, cleft palate $(1.5 \%)$, dental anomalies (1.5\%), congenital renal anomalies $(1.5 \%)$, skeletal anomalies $(0.8 \%)$, bimanual synkinesis $(0.8 \%)$. Uni or bilateral cryptorchidism was present in $29.7 \%$ of the men and all patients whose penile size could be assessed pre-treatment had micropenis. Family history of $\mathrm{CHH}$ or pubertal delay was present in 20 patients (15.4\%).

Most patients (107 cases) were selected from a large cohort previously studied by Sanger sequencing for the classical CHH-associated genes $(9,10,17,18,19,20,21$, 22, 23) (ANOS1, GNRHR, GNRH1, FGFR1, FGF8, PROKR2, PROK2, TACR3, TAC3, KISS1R and KISS1) (Supplementary Table 1 , see section on supplementary data given at the end of this article).

\section{Genetic analysis}

Genomic DNA was extracted from peripheralblood leukocytes of all patients and their relatives when available. A custom SureSelectXT DNA target enrichment panel (Agilent Technologies Inc) was designed to capture 36 known and candidate $\mathrm{CHH}$ 
genes. All exons, the 25 base pairs of intronic flanking region and $5^{\prime}$ and $3^{\prime}$ untranslated region of each gene were sequenced. The panel covered genes classically associated with $\mathrm{CHH}$, genes rarely or anecdotally reported in $\mathrm{CHH}$ patients and seven candidate genes, namely EBF2, GHSR, MSX1, MKRN3, OTX2, IGSF1 and IGFALS, based on data from biochemical/biological pathways or present in correlated conditions affecting the gonadotropic axis (Table 1).

Sequence capture was performed according to the SureSelectXT Target Enrichment protocol using Agilent Bravo Automated Liquid Handling Platform; sequencing was performed on a NextSeq 500 (Illumina, Inc). All preparations and sequencing were performed at the University of Sao Paulo (Large Scale Sequencing Laboratory - SELA).

Table 1 Genes selected for the NGS panel.

\begin{tabular}{|c|c|c|}
\hline Gene & GeneCards ID & Reference \\
\hline ANOS1 & GCOXM008528 & Legouis et al. (56) \\
\hline FGFR1 & GC08M038411 & Dodé et al. (49) \\
\hline FGF8 & GC10M101770 & Falardeau et al. (50) \\
\hline GNRH1 & GC08M025419 & Bouligand et al. (43) \\
\hline GNRHR & GC04M067737 & de Roux et al. (7) \\
\hline TAC3 & GC12M057009 & Topaloglu et al. (57) \\
\hline TACR3 & GC04M103586 & Topaloglu et al. (57) \\
\hline KISS1 & GC01M204190 & Topaloglu et al. (58) \\
\hline KISS1R & GC19P000917 & de Roux et al.(7)/Seminara et al. $(59,60)$ \\
\hline PROK2 & GC03M071820 & Dodé et al. (61) \\
\hline PROKR2 & GC20M005301 & Dodé et al. (61) \\
\hline CHD7 & GC08P060678 & Kim et al. (46) \\
\hline FGF17 & GC08P022042 & Miraoui et al. (32) \\
\hline SEMA3A & GC07M083955 & Young et al. (62) \\
\hline SEMA7A & GC15M074409 & Känsäkoski et al. (63) \\
\hline IL17RD & GC03M057124 & Miraoui et al. (32) \\
\hline HS6ST1 & GC02M128236 & Tornberg et al. (51) \\
\hline RNF216 & GC07M005661 & Margolin et al. (64) \\
\hline DUSP6 & GC12M089347 & Miraoui et al. (32) \\
\hline WDR11 & GC10P120851 & Kim et al. (65) \\
\hline POLR3A & GC10M077969 & Saitsu et al. (66) \\
\hline POLR3B & GC12P106357 & Saitsu et al. (66) \\
\hline FLRT3 & GC20M014322 & Miraoui et al. (32) \\
\hline SPRY4 & GC05M142272 & Miraoui et al. (32) \\
\hline sox10 & GC22M039963 & Pingault et al. (53) \\
\hline$N S M F$ & GC09M137447 & Miura et al. (67) \\
\hline MKRN3 & GC15P024015 & Abreu et al. (68) \\
\hline MSX1 & GC04P004861 & Xie et al. (69) \\
\hline OTX2 & GC14M056799 & Diaczok et al. (54) \\
\hline EBF2 & GC08M025841 & Trarbach et al. (70) \\
\hline GHSR & GC03M172443 & Pugliese-Pires et al. (71) \\
\hline IGSF1 & GCOXM131273 & Sun et al. (72) \\
\hline$D M X L 2$ & GC15M051447 & Tata et al. (73) \\
\hline IGSF10 & GC03M151425 & Howard et al. (47) \\
\hline IGFALS & GC16M001790 & Domené et al. (74) \\
\hline PNPLA6 & GC19P007534 & Topaloglu et al. (75) \\
\hline
\end{tabular}

NGS, next-generation sequencing.

\section{Variant analysis}

Data analysis was performed using in-house bioinformatics pipeline. Briefly, paired-end reads were aligned to the b37+decoy version of the human genome using $b w a$, followed by downstream processing of the aligned reads (sorting, merging and indexing) using the bamsort tool from biobambam2 $(25,26)$. We used fastqc (https:// www.bioinformatics.babraham.ac.uk/projects/fastqc/) and qualimap to assess sequencing quality and target regions coverage metrics, respectively (27). Variant calling was performed using freebayes. Finally, variants were normalized with $v t$ and annotated using annovar $(28,29)$.

The panel sequencing data were screened for rare (minor allele frequency less than 1\% in public and in-house databases), nonsynonymous, located in exonic regions and consensus splice site variants. Subsequently, variant filtration prioritized genes on the basis of their potential to be pathogenic: loss-of-function variants and variants predicted to be pathogenic by at least two in silico programs (SIFT, PolyPhen2, Mutation Taster, Mutation Assessor, Functional Analysis through Hidden Markov Models - FATHMM, Protein Variation Effect Analyzer PROVEAN, Combined Annotation Dependent Depletion - CADD). For variants affecting splicing sites, we used in silico prediction sites: Human Splicing Finder Version 2.4.1 (http://www.umd.be/HSF/) and NetGene2 (http:// www.cbs.dtu.dk/services/NetGene2/). In silico analysis included the exclusive selection of variants with GERP (genomic evolutionary rate profiling) $>2.5$.

Population data criteria were evaluated with the help of two public genomic databases: Genome Aggregation Database (GnomAD: http://gnomad. broadinstitute.org/), Online Archive of Brazilian Mutations (ABraOM: http://abraom.ib.usp.br/) (30), composed of 609 exomes of healthy Brazilians elderly, and an in-house database comprising data from exomic sequencing covering 774 alleles (Large Scale Sequencing Laboratory - SELA). All rare variants considered potentially pathogenic were visually confirmed in the Integrative Genomics Viewer (IGV) program, from the BAM file. All potential disease-causing variants were confirmed by Sanger sequencing. Familial segregation was performed whenever genetic material of relatives was available.

The variants were further classified for pathogenicity according to the criteria of the American College of Medical Genetics (ACMG) and the Association for Molecular Pathology (AMP) guidelines (31). Furthermore, all these variants were interpreted based on the phenotype 
to which the variant was associated, pattern of genetic inheritance and segregation data.

\section{Copy number variation analysis}

Copy number variations (CNVs) were screened using the CONTRA (REF: PMID 22474122). To infer segmental copy number status for each patient, each individual BAM file was compared to a pooled reference constituted of all individuals included in the analysis.

\section{RNA isolation and RT-PCR for the GnRH1}

Lymphocytes were isolated from peripheral lymphocytes from the index case, his mother and a healthy adult control with normal pubertal development using the Ficoll-Hypaque method. Total RNA was extracted using TRIzol ${ }^{\circledR}$ (Invitrogen) and reverse transcribed using the QuantiTect Reverse Transcription Kit (Qiagen, 2009) according to the manufacturer's instructions. GNRH1 cDNA was amplified with a specific primer pair located at exons 1 and 2, comprising the splicing region of interest between exons 1 and 2. PCR product was visualized in $2 \%$ agarose gel, purified and automatically sequenced in an ABI Prism Genetic Analyzer 3100 (Perkin-Elmer).

\section{Multiplex ligation-dependent probe amplification}

SOX10 gene deletion was confirmed using the SALSA MLPA P186 PAX3-MITF-SOX10 probemix (MRC Holland, Amsterdam, Netherlands) that includes probes for all four exons of SOX10 gene. The peak area for each probe was determined with GeneScan analysis software V.3.7 and normalized by combined value of the control probes in corresponding lane. This relative value was compared to those obtained in two normal controls (DNA references) using Cofallyser. Final probe ratios of 0.5 were considered positive for heterozygous deletion.

\section{Results}

\section{Genetic findings}

The lowest coverage was $98 \%$ of the targeted regions with coverage greater than 20 times, and the vast majority of patients had coverage greater than 50 times in $99 \%$ of the target regions, indicating that the quality of the sequencing was very satisfactory.

Potentially pathogenic variants were identified in 77 $(59.2 \%)$ of the $130 \mathrm{CHH}$ patients studied with targeted
NGS approach. A total of 89 different variants were detected in 29 genes (Fig. 1 and Table 2). However, after applying the ACMG-AMP guidelines, the number of individuals considered to carry pathogenic or probably pathogenic variants dropped to 43 (33\%) (Fig. 2). Clinical and molecular characterization of all patients is described in Supplementary Table 2. Variants in genes with known autosomal recessive inheritance were not considered causative of the phenotype when identified in the heterozygous state. Variants which did not segregate in the family or which were present in healthy individuals databases were classified as benign. Detailed data on variants considered pathogenic and probably pathogenic are exposed in Table 3. No rare variants were identified in KISS1, KISS1R, HS6ST1; genes previously associated to $\mathrm{CHH}$, and in the candidate genes DUSP6, GHSR, MSX1 and MKRN3.

\section{Pathogenic and probably pathogenic variants}

\section{Variants in classical $\mathrm{CHH}$ genes}

The majority of pathogenic or probably pathogenic variants were identified in classical $\mathrm{CHH}$ genes. The FGFR1 was the most prevalent gene with 11 variants, five in KS and six in $\mathrm{nCHH}$ patients (8.5\%). Additional nonreproductive abnormalities were observed in three patients with FGFR1 mutations: Patient 16 (p.Arg250Trp) with dental agenesis, epilepsy, mild cognitive deficit, unilateral hearing loss and synkinesia, Patient 19 (p.Ala343Val) with bilateral hearing

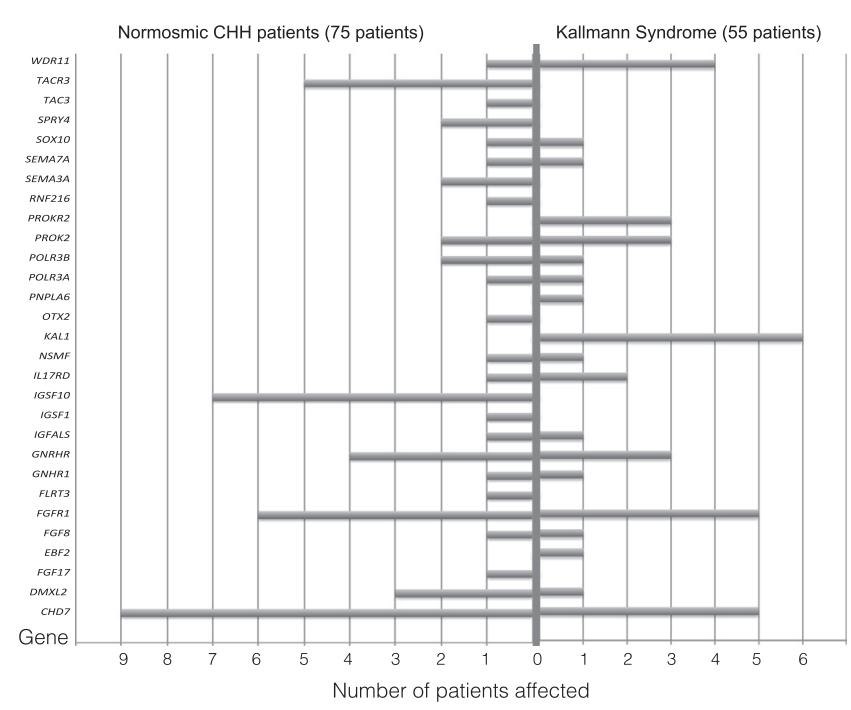

Figure 1

Rare variant identified by NGS in 130 patients with $\mathrm{CHH}$. 


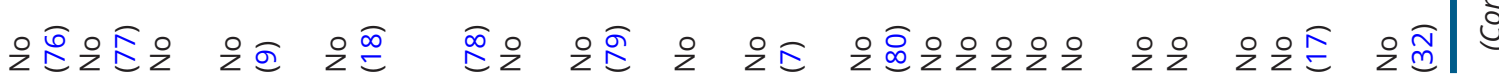

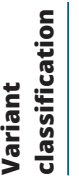

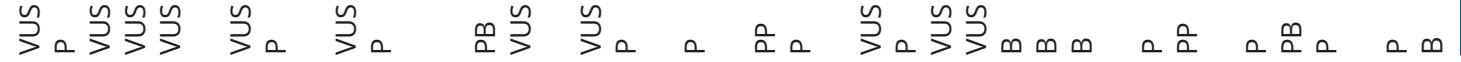

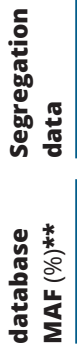

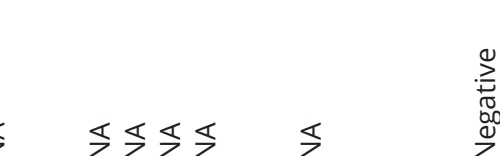

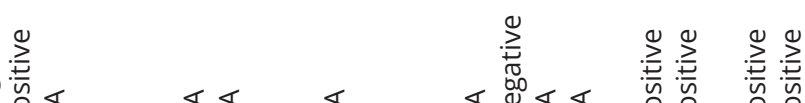

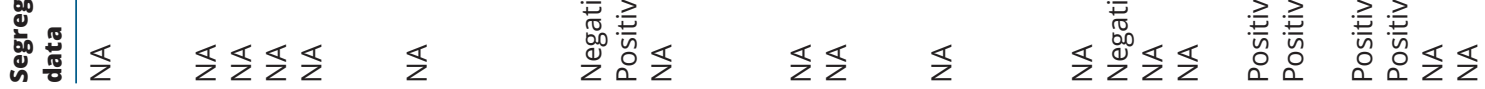

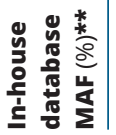

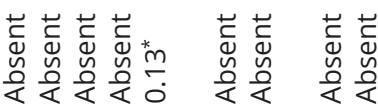

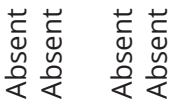

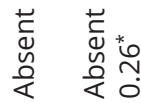

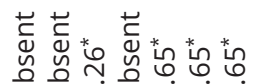

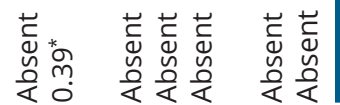

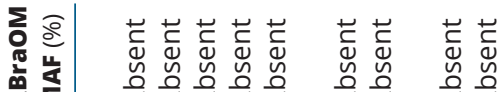

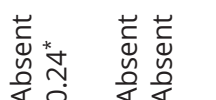

若

蒂䒧

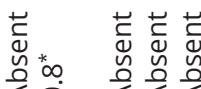

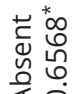

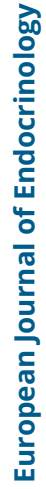

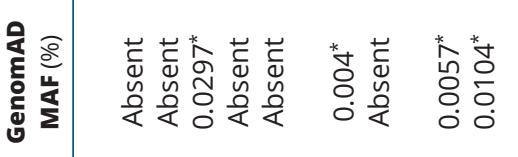

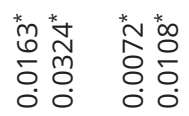

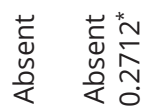

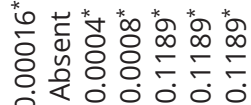

苋

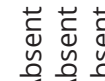

苍高

胥

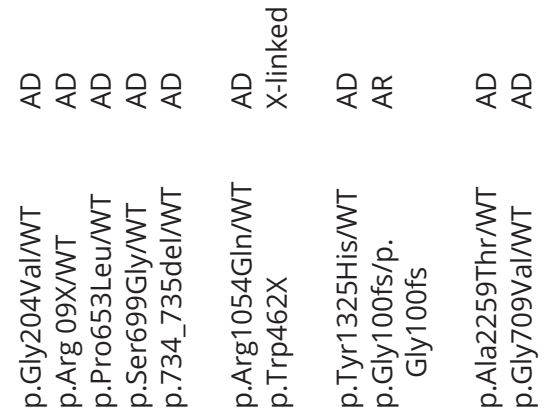

虽安采

是采是是是的是是是

是是是妥最是是

$\therefore \circ \stackrel{2}{0}$
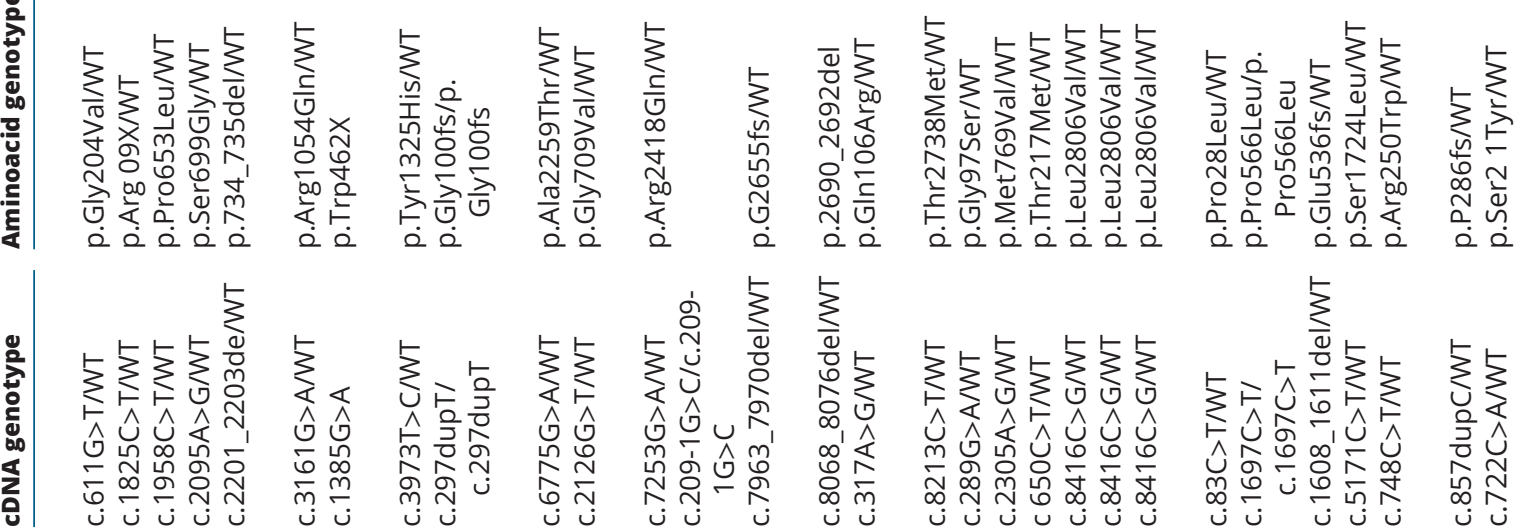

点

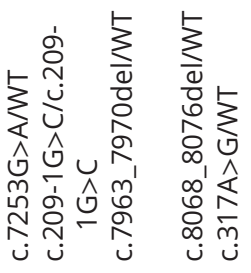

ن

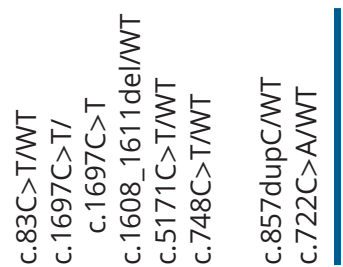

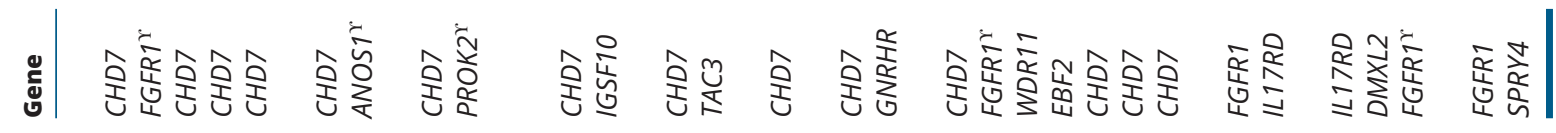

ํํำ $\underline{\underline{y}}$

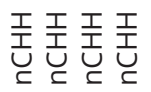

๒ิ 志

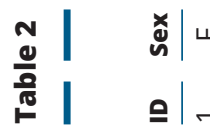

$\Sigma \Sigma \Sigma \Sigma$

$\sim m \forall n$

6

$\Sigma \Sigma \quad \Sigma$

$\Sigma \Sigma \leftarrow \Sigma$

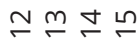

$\Sigma u$

$a ㄷ ㅜ$

$\because \approx$ 


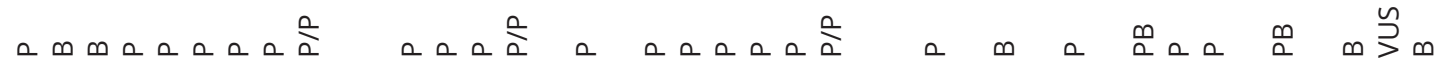

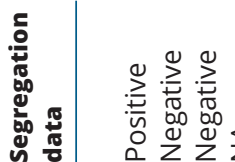

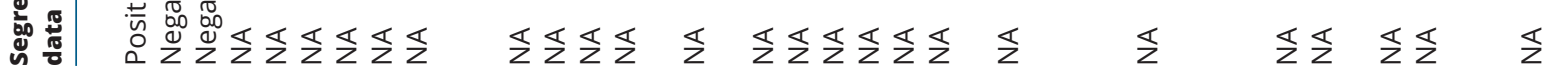

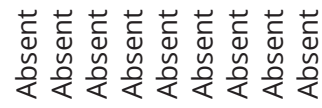

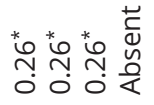

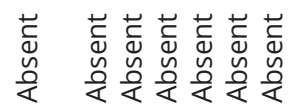

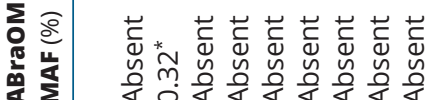

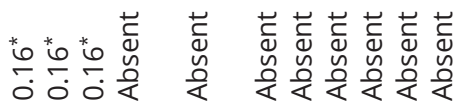

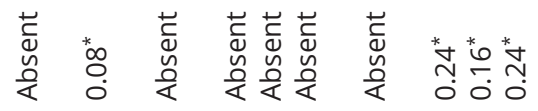
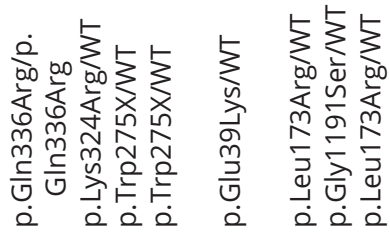

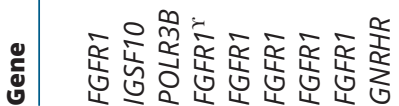

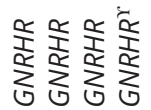

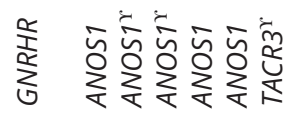
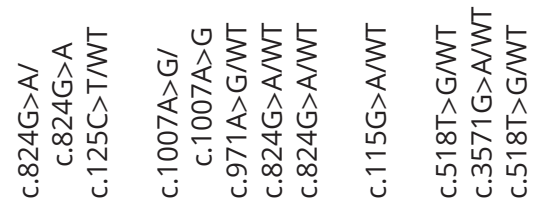

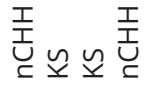

志

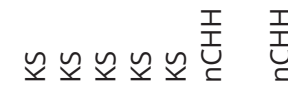

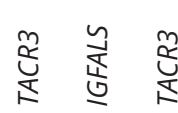

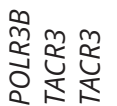

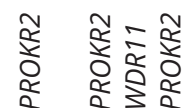

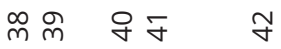




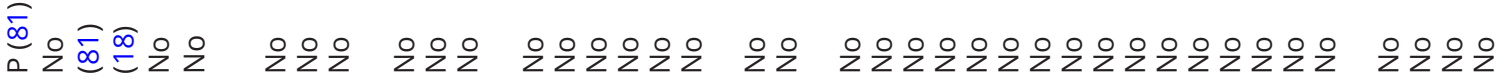

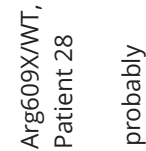

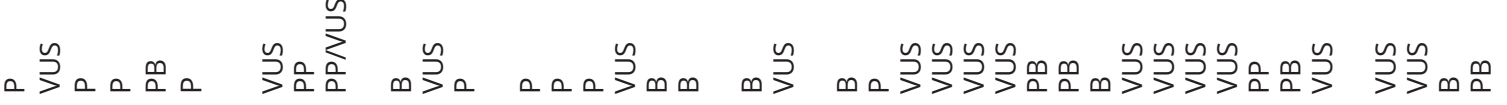

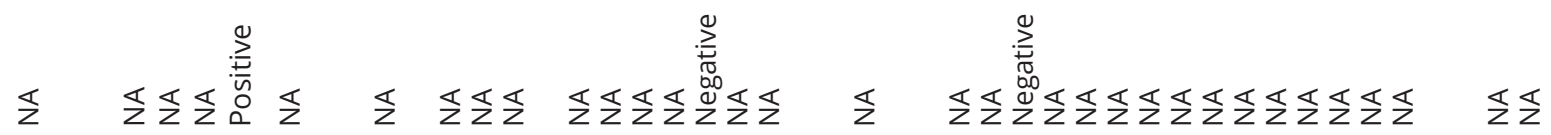

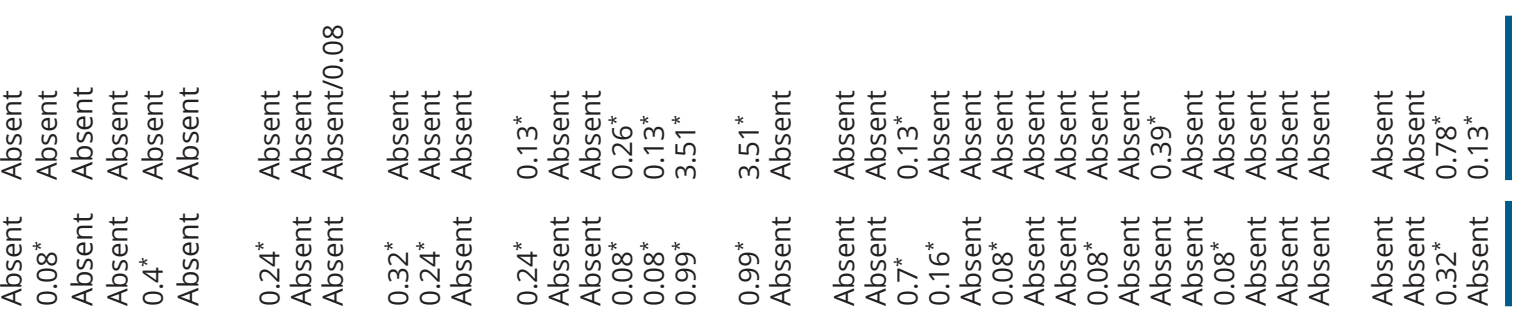

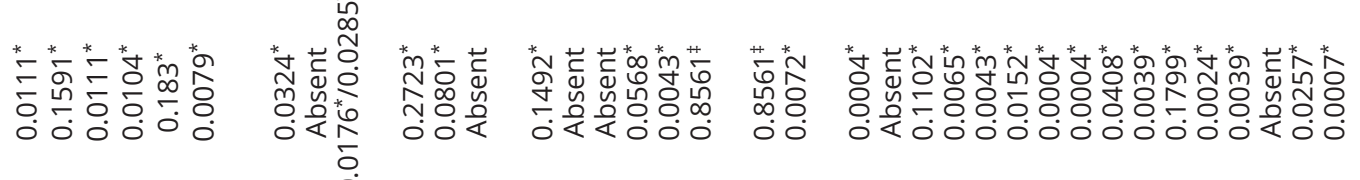

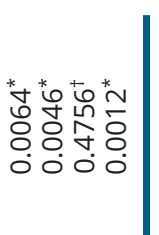

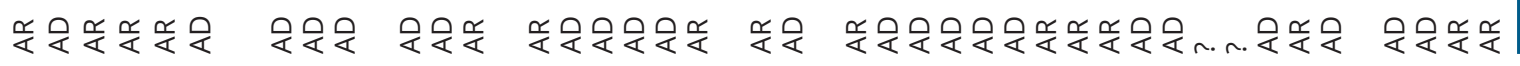

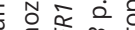

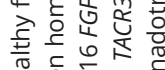

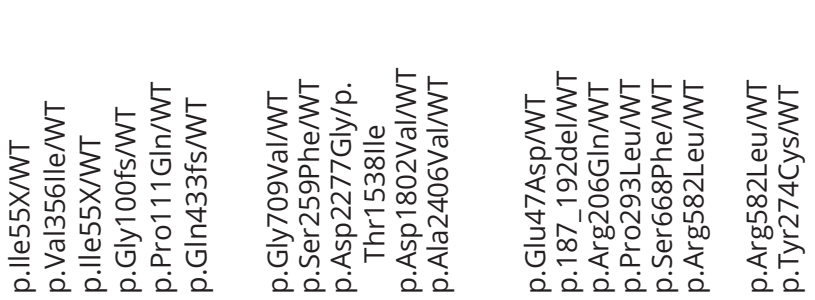
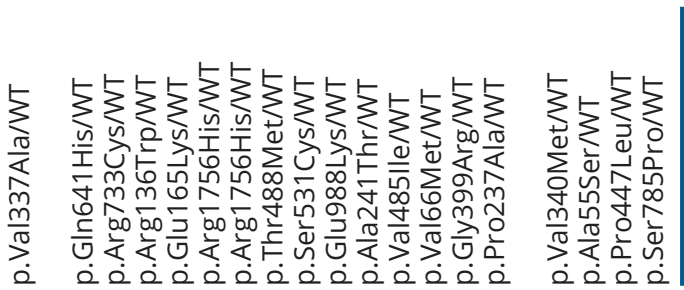

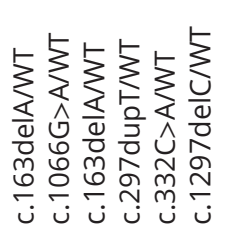

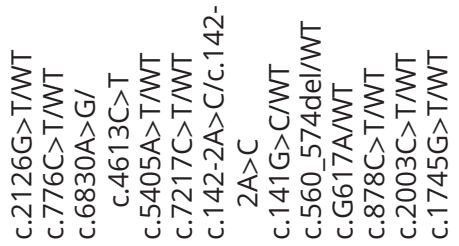
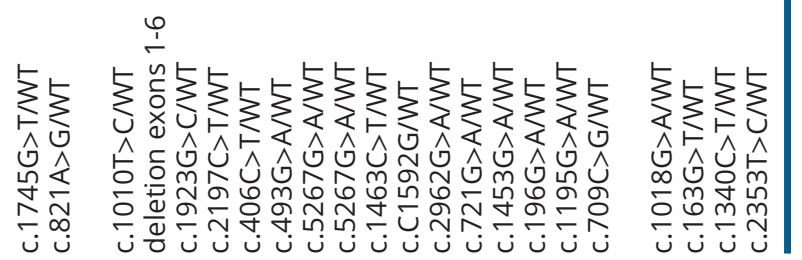

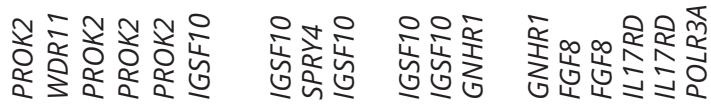

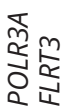

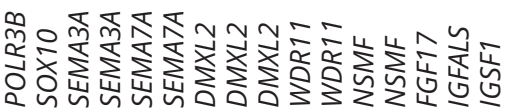

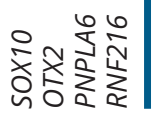

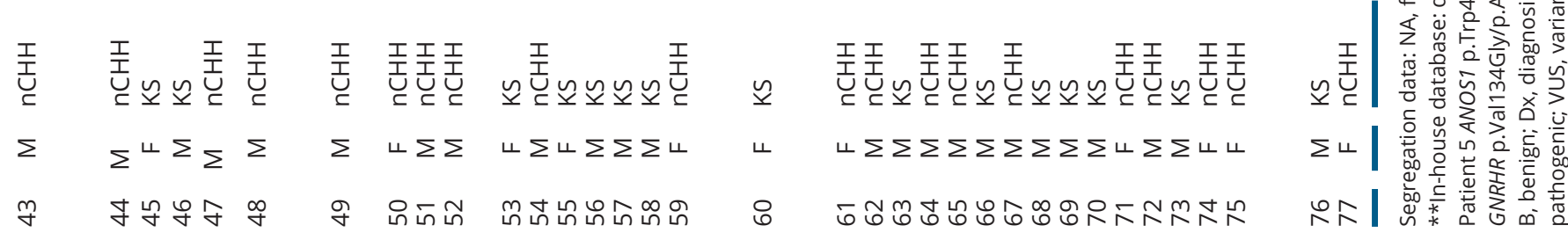




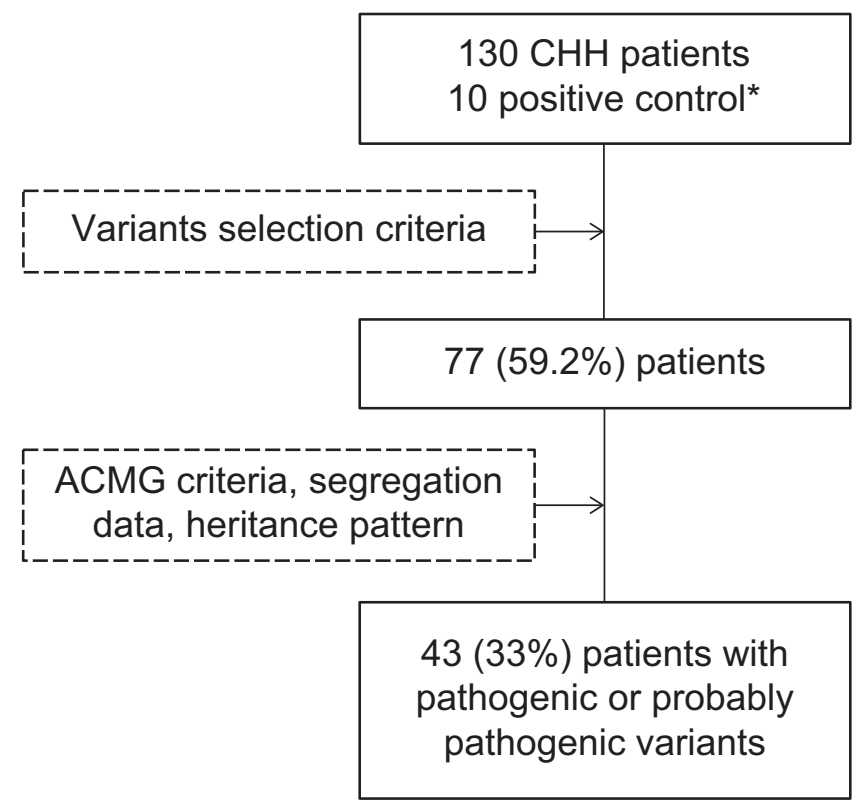

Figure 2

Flowchart for the selection of candidate variants.

loss and Patient 23 (p.Cys767Tyr) with ogival palate and unilateral deafness. ANOS1 mutations were identified in six men with KS, all with complete hypogonadism phenotype (4.6\%). Patient 31 (p.Ala30fs) had bilateral cryptorchidism, ogival palate and mild cognitive deficit. Biallelic mutations in the GNRHR gene were identified in three patients with $\mathrm{CHH}$ (2.3\%) (Table 2). One of these patients presented with reversal hypogonadism with subsequent relapse (Patient 28, carrying the variants p.Val134Gly/p.Arg262Gln). The well-known partially inactivating variant p.Gln106Arg was identified in four patients, but not considered enough to explain the phenotype because it was in the heterozygous state in all instances $(7,10)$.

\section{A novel mutation in GNRH1}

A homozygous splicing site mutation (c.142-2A $>$ C) in the GNRH1 gene was identified in a male patient (Patient 52), with no other molecular variant identified. The patient presented at 18 years of age complaining of lack of pubertal development, history of bilateral cryptorchidism, surgically corrected in childhood and no other associated condition. He was born to consanguineous parents and had no other affected member in the family. At physical examination, he had pubic hair Tanner stage III, micropenis, testicular size $1.5 \times 1.0 \mathrm{~cm}$, left and $2.0 \times 1.4$ right, BMI $27 \mathrm{~kg} / \mathrm{m}^{2}$, with eunuchoid proportions. He reported a normal sense of smell, confirmed by smell test. Hormonal evaluation revealed total testosterone $11 \mathrm{ng} / \mathrm{dL}$ (prepubertal $<12 \mathrm{ng} /$ $\mathrm{dL}$, adults $271-965 \mathrm{ng} / \mathrm{dL}), \mathrm{LH}<0.1 \mathrm{IU} / \mathrm{L}(1.5-8.4 \mathrm{IU} / \mathrm{L})$, FSH $<1 \mathrm{IU} / \mathrm{L}(1.7-12.4 \mathrm{IU} / \mathrm{L})$. Other tests of anterior pituitary function were normal, as well as a magnetic resonance imaging (MRI) scan of the hypothalamopituitary region, establishing the diagnosis of $\mathrm{CHH}$. The c.142-2A $>C$ variant was identified in the heterozygous state in the patient's unaffected sister and his parents (Fig. 3A). Human Splicing Finder version 2.4.1 and NetGene2 in silico tools predicted the c.142-2A $>$ C variant to damage the natural acceptor splicing site in intron 2-3 while simultaneously activating a cryptic acceptor site. In fact, an aberrant GNRH1 transcript harboring a deletion of $4 \mathrm{bp}$ (c.142-145delATAG) was detected in patient's lymphocytes. This deletion leads to a frameshift and a subsequent premature stop codon at aminoacid position 74 . mRNA levels of the wild-type and mutated GNRH1 were detected in lymphocytes from the patient and his mother (Fig. 3B).

\section{CHD7 variants}

A total of 12 distinct rare $C H D 7$ variants were identified in 14 patients with $\mathrm{KS}$ and $\mathrm{nCHH}$ (Table 2). However, after applying the ACMG criteria, 12 variants were lately classified as uncertain clinical significance (VUS) and two, p.G2655fs and p.2690_2692del, identified in Patients 9 and 10, were classified as pathogenic and probably pathogenic, respectively. Patient 9 had KS associated to hearing loss and body asymmetry and Patient 10, also heterozygous for the p.Gln106Arg GNRHR mutation, had KS, dental agenesis, high arched palate and kidney anomalies (Supplementary Table 2). Five of these patients had associated pathogenic variants in known $\mathrm{CHH}$ genes, which would alone be sufficient to cause the phenotype (FGFR1, ANOS1, TAC3, PROK2) (Table 2). Patient 3, whose only variant was a CHD7 p.Ser699Gly, of uncertain significance, had KS associated with unilateral renal agenesis and unilateral deafness.

\section{A large deletion of the SOX10 gene}

A large deletion involving the entire coding region of the SOX10 gene was identified in the heterozygous state in a woman with KS and bilateral sensorineural deafness (Patient $60)$. She presented at 19 years of age, with lack of pubertal development, primary amenorrhea and absent sense of smell. She had a severe bilateral sensorineural hearing loss. 
|

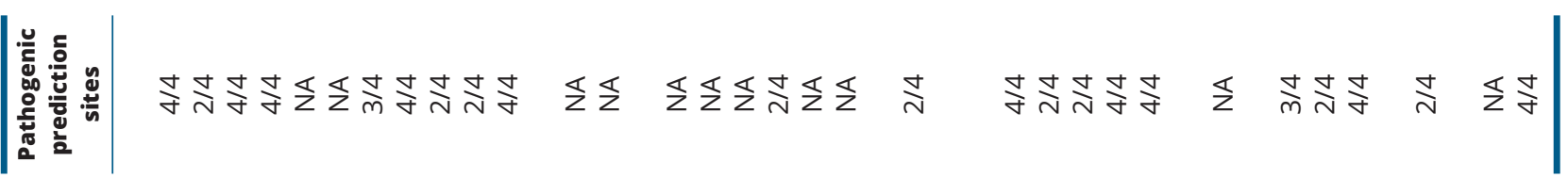

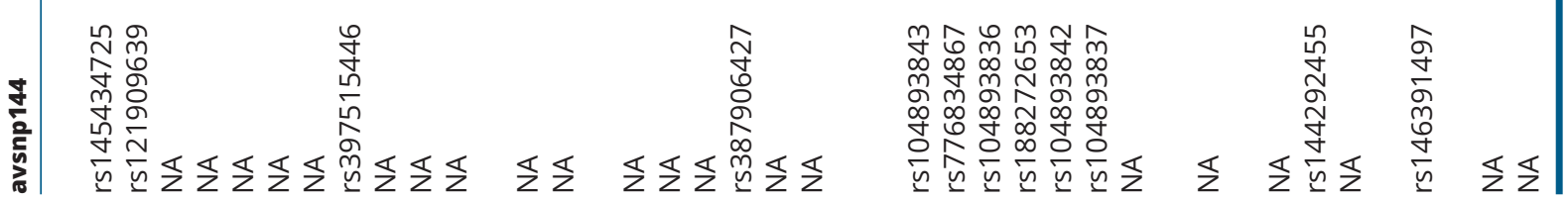

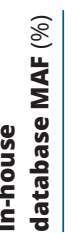

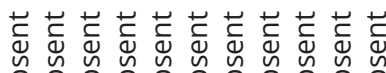

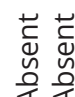

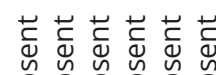

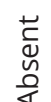

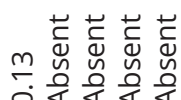

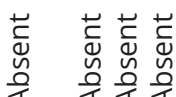

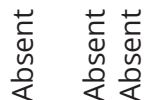

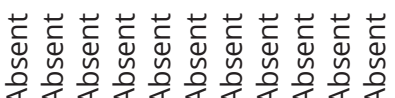

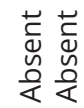

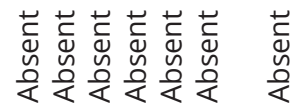

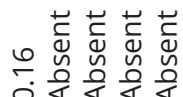

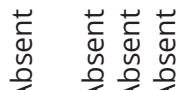

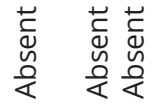

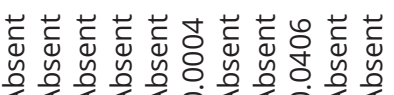

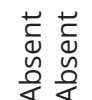

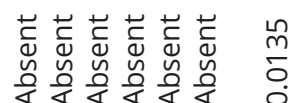

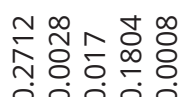

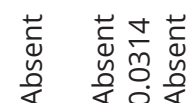

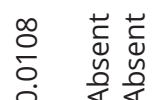

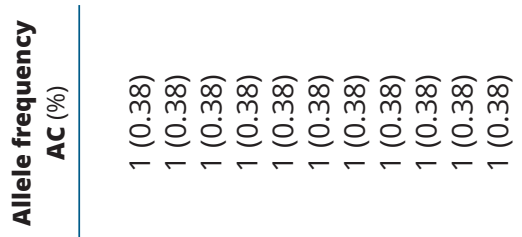

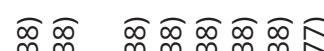

를

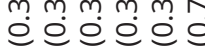

$\stackrel{\widehat{\infty}}{\stackrel{m}{\rho}}$

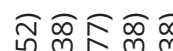

क $\bar{\infty} \hat{\sigma}$

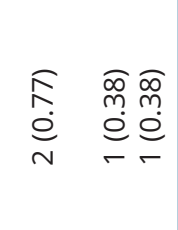

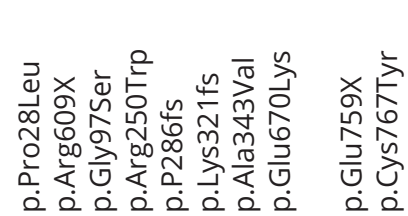

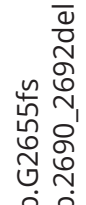

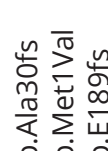

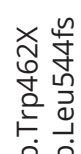
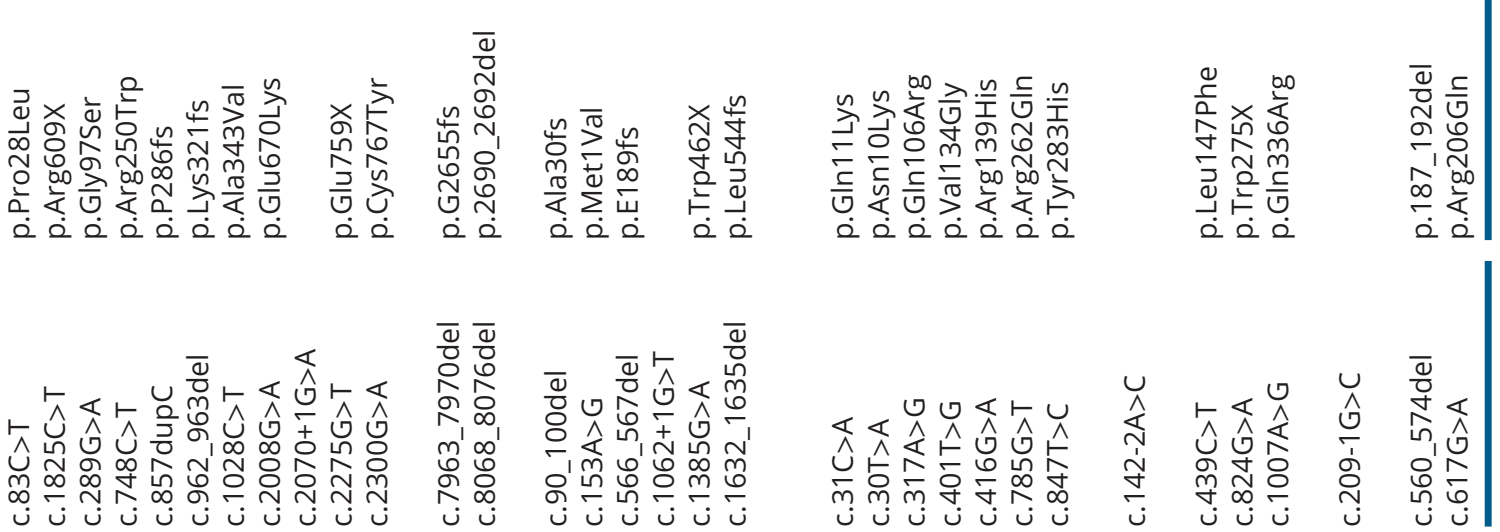

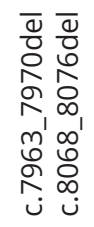

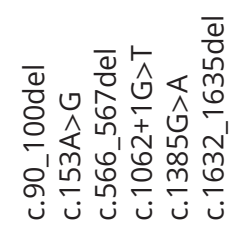

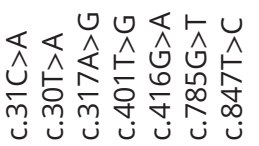

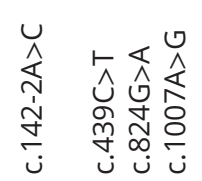

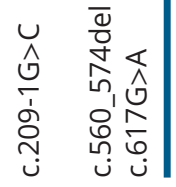

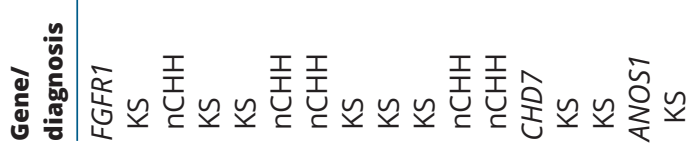

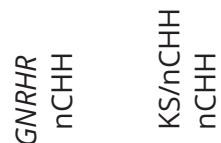

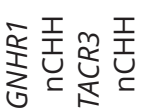

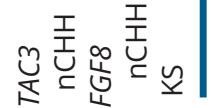




\begin{tabular}{|l|l|l|l|l|l|l}
$\mid$ & $\begin{array}{l}\text { At physical examination, she had no pubic hair and breast } \\
\text { development Tanner stage I, BMI 19kg/m² and bilateral } \\
\text { clinodactyly. Skin, hair or iris pigmentation abnormalities }\end{array}$ \\
were absent. Olfactory test confirmed anosmia. Hormonal \\
evaluation revealed prepubertal levels of serum estradiol,
\end{tabular}
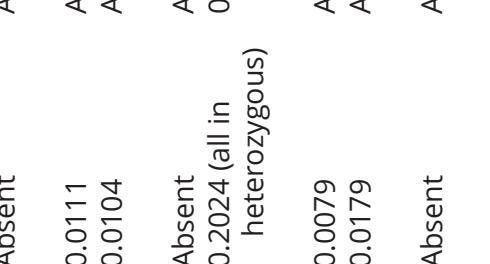

\section{Other rare variants}

Variants predicted to be pathogenic or probably pathogenic were identified in IGSF10, SPRY4, IL17RD and FGF17; some of them in oligogenicity with variants in other genes.

Rare IGSF10 variants were initially identified in eight patients, but after applying variant selection criteria, only Patient 49 (p.Asp2277Gly and p.Thr1538Ile) and Patient 47 (p.Gln433fs), both with $\mathrm{nCHH}$, were found to carry probably pathogenic and pathogenic variants, respectively.

A probably pathogenic variant was identified in FGF17 (p.Val66Met) in a man with $\mathrm{nCHH}$ and no additional phenotype (Patient 72). Two different pathogenic IL17RD variants, one homozygous (p.Pro566Leu) and one heterozygous (p.Glu536fs) were identified in a male patient with nCHH (Patient 15), who carried heterozygous rare variants in FGFR1 (p.Pro28Leu) and DMXL2 (p.Ser1724Leu) as well.

Rare variants were identified in FLRT3 (p.Tyr274Cys) in a woman with $\mathrm{nCHH}$ and sensorineural hearing loss (Patient 59), and in IGSF1, a candidate gene that has not been previously described in $\mathrm{CHH}$ patients. The IGSF1 p.Pro237Ala was identified in Patient 74, a woman with nCHH and no other endocrinopathies, with a family history of pubertal delay. Both FLRT3 and IGSF1 variants, however, are still considered of uncertain clinical significance, since the causative role of these genes in $\mathrm{CHH}$ is not yet sufficiently established in the literature.

\section{$\mathrm{CHH}$ reversal}

$\mathrm{CHH}$ reversal was defined as the presence of normal adult testosterone levels after hormone replacement 
A

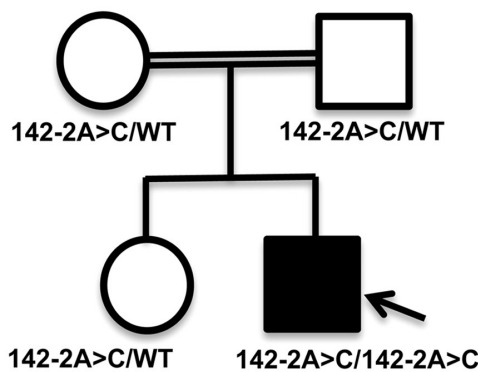

B

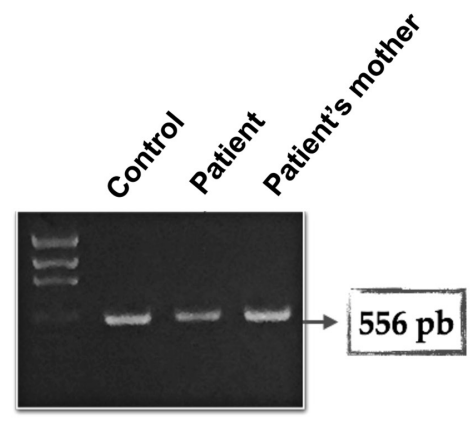

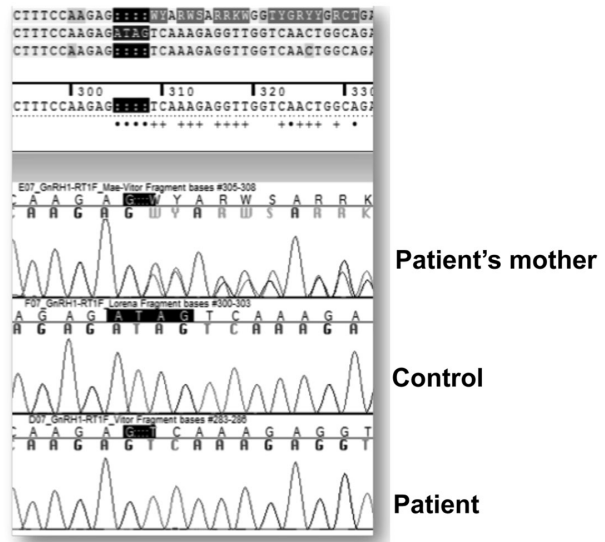

C

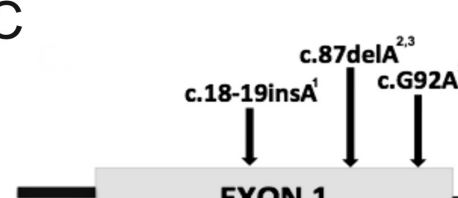

c.142-2A $>C$

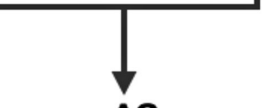

AG EXON 2

EXON 3

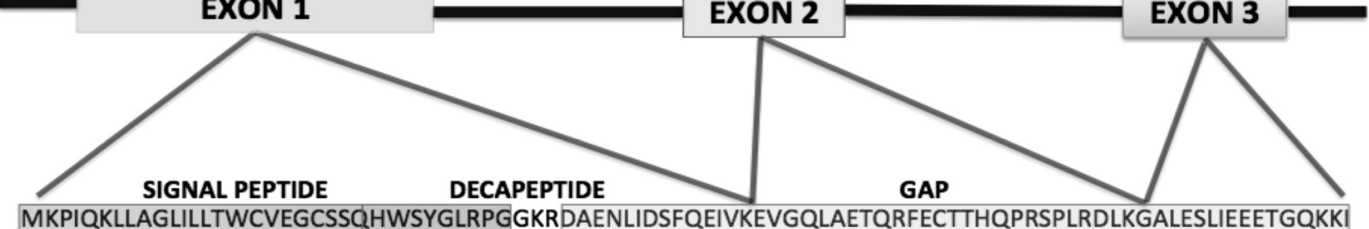

1. Bouligand, et al. NEJM, 2009

2. Chan, et al. PNAS, 2009

3. Topaloglu, et al. Horm Res Pediatr, 2016

\section{Figure 3}

(A) Family heredogram of patient with a GNRH1 mutation (squares indicate male family members, circles female family members, black symbols clinically affected patient - index, white circles phenotypically normal). (B) Amplification and automatic sequencing of cDNA fragment (556 bp) of GNRH1. (C) Schematic structure of GNRH1 with the localization of four homozygous mutations (three previously described).

was discontinued for an appropriate washout period (3-6 months for testosterone injections), and no symptoms of hypogonadism after cessation of treatment (32). Hypogonadism reversal was observed in 6/92 male patients participating in this study (6.5\%). Patients 47 and 49 had $\mathrm{nCHH}$ and probably pathogenic variants in the IGSF10 gene (p.Gln433fs and p.Asp2277Gly/ Thr1538Ile, respectively). Patient 28, also with nCHH, had a compound heterozygous mutation in the GNRHR gene (p.Val134Gly/Arg262Gln). Patients 27, 57 and 90 had KS, without established molecular diagnosis.

\section{Oligogenic findings}

Nine patients (6.9\%) presented with rare variants classified as pathogenic, probably pathogenic or VUS in more than one gene (Table 2 ). The gene most commonly identified in association with others was CHD7 followed by FGFR1. In the majority of these patients, however, one of the variants alone would be sufficient to explain the phenotype. The role of these variants together in the pathogenesis of $\mathrm{CHH}$ is unknown, and one cannot discard the possibility of a synergistic role for these variants in the patients' phenotype.

\section{Discussion}

We investigated the presence of rare genetic variants in patients with $\mathrm{KS}$ and $\mathrm{nCHH}$, using a 36 genes panel, which included 29 genes previously associated with $\mathrm{CHH}$ and seven candidate genes. With this approach it was possible to identify pathogenic or probably pathogenic variants in 42/130 patients (32.3\%). Miraoui et al. (2013) analyzed 17 genes in $350 \mathrm{CHH}$ individuals and identified mutations in $35 \%$ of the cases (32). Most recently, Cassatella et al. 
(2018) screened 24 genes on $116 \mathrm{CHH}$ patients and identified rare variants in $51 \%$ of the cases, though with less rigorous selection criteria than ours (33). Although the selection of genes was somewhat different from ours, the most frequently affected genes were quite the same in all works $(32,33)$. In the literature, the percentage of patients with identified mutations varies from 30 to 50\% (12, 32, $33,34,35,36)$. This variation may be probably attributed to factors as choice of genes to be studied, technique used, variants selection criteria and interpretation of data. It is remarkable to observe that though targeted NGS was able to increase the percentage of patients with a molecular diagnosis, genes classically associated to $\mathrm{CHH}$ remains responsible for most of the cases in all studies.

In this work, FGFR1 and ANOS1 were the most frequently affected genes, followed by GNRHR. It is important to remind that $107 / 130$ patients studied here had already been screened by Sanger sequencing for the main $\mathrm{CHH}$ genes, as part of a previously studied cohort of 260 patients, $22.3 \%$ of them with established molecular diagnosis. Notably, many patients with previously identified deleterious mutation in genes as ANOS1 and GNRHR, among others, were not included in the present study. Considering the new genetic findings identified in this panel in addition to the mutations previously identified by Sanger sequencing, we have a prevalence $35 \%(99 / 283)$ of all patients with molecular diagnosis, confirming FGFR1 (11.2\%), ANOS1 (10.2\%), and GNRHR $(9.4 \%)$ as the most frequently affected genes, considering only $\mathrm{nCHH}$ patients for GNRHR and only KS patients for ANOS1. These findings strengthen the importance of these genes in the pathogenesis of $\mathrm{CHH}$. The prevalence of mutations in the classical $\mathrm{CHH}$ genes in our cohort is in agreement to the described in the literature, although the frequency of mutations in each specific gene is somehow variable in different publications, possibly due to baseline differences in the selection of populations studied, ethnicity, frequency of familial cases and consanguineous families $(5,10,12,32,34,35,37,38,39,40,41)$.

GNRH1 has been considered for several years an obvious candidate for mutations in patients with $\mathrm{nCHH}$, but so far only three different homozygous mutations have been described (Fig. 3C) $(42,43,44)$. In our study, we identified a novel GNRH1 homozygous mutation located at the consensus splicing site region upstream the start of exon 2 (c.142-2A>C). Interestingly, this mutation does not affect the transcription of GnRH decapeptide, completely encoded by exon 1 . However, it predicts a loss of the GnRH-associated peptide (GAP), which corresponds to the same region that is lost in the natural animal model of deficiency of GnRH, the hpg mouse (45). One plausible hypothesis is that the variant, resulting in a premature stop/termination codon (PTC), lead to GNRH1 mRNA nonsense-mediated decay (NMD), in which case no GnRH is produced, thus explaining the phenotype. Though, the recognition of the PTC depends of several factors including the distance between the nonsense codon and the downstream exon-exon junction. In the aberrant transcript described here this distance is 14 base pair, less than 50-55 nucleotides required to effective RNAm degradation triggered by Nonsense-Mediated mRNA Decay. This unprecedented finding of a putative loss-offunction variant in this position gives us the opportunity to elucidate the functional importance of the GAP region, which has not yet a defined function (45).

The CHD7 gene encodes a chromodomain helicase DNA binding protein 7 , which plays a relevant role in the neuronal development of the olfactory bulb and GnRH neurons (46). CHD7 loss-of-function mutations of the gene have been classically associated with CHARGE syndrome (OMIM 214800), a multisystem disorder characterized by the presence of coloboma, cardiac abnormalities, choanal atresia, developmental delay, genital and ear anomalies (46). The seminal study conducted by Kim et al. (2008) first demonstrated heterozygous mutations of CHD7 in patients with KS and no other CHARGE features (46). To date, the overall prevalence of $\mathrm{CHD} 7$ mutations is approximately $7 \%$ in patients with KS, however, when associated with the deafness and KS, it can achieve nearly $40 \%$ of patients $(4,5)$. Notably, CHD7 sequencing analysis had not been previously performed in this Brazilian cohort. Although CHD7 mutations have also been reported in a high frequency in other $\mathrm{CHH}$ cohorts (5), this selection bias actually could partially explain the higher prevalence of CHD7 findings in our cohort. It is important to take into consideration that the CHD7 is a large gene with a lot of rare missense variants reported in GnomAD. It is therefore not uncommon to find a rare variant unrelated to the phenotype in such a gene simply by chance. Consequently, most of the variants identified in this gene should be interpreted with caution, and in this study most of them were classified as VUS. Three patients with $\mathrm{CHD} 7$ variants had additional phenotypic features (deafness and kidney defects) corroborating the concept that these characteristics are more frequently in patients with mutations in this gene $(5,46)$. Segregation analysis was possible in three families and in two of them (patients 7 and 12), the same variants were identified in healthy relatives (p.Ala2259Thr and p.Leu2806Val), 
weakening the importance of $C H D 7$ in the pathogenesis of $\mathrm{CHH}$ in these patients.

Recently, the knowledge aboutIGSF10 functions related to the gonadotrophic axis and GnRH neurons has been deepened. In 2016, The IGSF10 gene has been associated with self-limited delayed puberty and functional forms of GnRH deficiency (47). In the present study, we identified probably pathogenic or pathogenic IGSF10 variants in two male patients with nCHH. Interestingly, both patients presented with reversion of the hypogonadism. Reversibility has been described in approximately $10 \%$ of $\mathrm{CHH}$ cases after sex steroids replacement therapy, especially in patients with partial CHH (48). In the present study, four other patients had reversible $\mathrm{CHH}$, one with a compound heterozygous mutation in GNRHR, a gene previously associated to reversibility of hypogonadism (10), and three patients with no identified pathogenic mutations so far. Howard et al. (2016) hypothesized that defects in IGSF10 leads to delayed puberty through dysregulation of GnRH neuronal migration during embryonic development (47). It is possible that IGSF10 plays a temporal role in GnRH neurons migration and plasticity modulation, allowing the immature neurons to complete their development when submitted to sex hormones stimulation. We hypothesize that IGSF10 defects may be represent a common basis to different presentations of transient GnRH deficiency, including functional hypogonadotropic hypogonadism, self-limited delayed puberty and reversible CHH. Functional studies to assess the consequences of these specific variants could clarify these issues, but the current results already enrich our knowledge about the likely role of IGSF1O in CHH.

The FGFR1 signaling complex plays a crucial role in the migration of olfactory and GnRH neurons, acting in synergy with anosmin-1, and its involvement in the pathogenesis of $\mathrm{CHH}$ is well-known $(38,49,50)$. Genes involved in the FGFR1 signaling pathway were associated with CHH, including IL17RD, HS6ST1, FGF17, FLRT3 and SPRY $4(32,51)$.

Mutations in the IL $17 R D$ gene were initially described in KS associated with deafness and subsequently in some cases of puberty delay $(32,52)$. Previous studies have suggested that only one allelic defect in the IL17RD gene would probably not be sufficient to cause the $\mathrm{CHH}$ phenotype and additional affected alleles in the same or other genes would be required for the KS phenotype $(32,52)$. Therefore, it was suggested that variants in heterozygosis in IL17RD could result in reproductive endocrine phenotypes of varying severity (32). In Patient 15, with nCHH without deafness, two variants were identified in $I L 17 R D$, a homozygous missense in associated with a heterozygous frameshift. This patient also presented heterozygous variants in FGFR1 and DMXL2 genes. The variants of IL17RD and FGFR1 were classified as pathogenic and the DMXL2 variant as probably benign; the degree of contribution of each variants to the $\mathrm{CHH}$ phenotype is unknown. Until now, mutations in IL17RD gene had been described only in patients with KS and puberty delay, often with the associated deafness phenotype.

The FLRT3, FGF17 and SPRY4 include the set of genes expressed and regulated during development in a similar manner to the FGF8. Miraoui et al. (2013) described variants in FLRT3 in KS patients and in FGF17 and SPRY4 in both KS and nCHH patients (32). We identified two variants in SPRY4 in patients with nCHH: p.Ser259Phe (Patient 48), classified as probably pathogenic, and p.Ser241Tyr (Patient 17), classified as benign for its presence in the heterozygous and homozygous state in $\mathrm{ABraOM}$ and GnomAD databases. Indeed, Patient 17 also carried a FGFR1 mutation (p.Pro286fs), enough to justify the phenotype. Heterozygous variants in FGF17 (p.Val66Met) and FLRT3 (p.Tyr274Cys) were identified in patients with $\mathrm{nCHH}$ and classified as probably pathogenic and VUS, respectively. Patient 59, with the FLRT3 p.Tyr274Cys variant, had normal olfaction and unilateral hearing loss, different from the initial description of the association of this gene with KS without deafness (32). Considering the relation of FLRT3 with the FGF8/FGFR1 pathway, which is associated a variable phenotypic spectrum, we raise the possibility that the patient described here might represent a new variation of the phenotype associated with FLRT3 defects.

SOX10 gene plays a major role in neural crest development and is known as the causative gene of Waardenburg syndrome (WS), characterized by skin/ hair/iris hypopigmentation, deafness and other variable neuronal defects. SOX10 has recently been associated to KS and hearing loss (53). We describe here a deletion of the whole coding sequence of SOX10 in a patient with KS and deafness. This finding provides further evidence for the significance of SOX10 mutations as genetic cause of KS, especially when associated with deafness, and suggests a lack of genotype-phenotype correlation since a large deletion, as described here, is not associated with the complete WS phenotype.

OTX2 mutations have been described in association with a clinical syndrome involving multiple pituitary gland deficiency or with retinal dystrophy without pituitary deficiencies (54). We identified an OTX2 variant 
in association with a SOX10 variant, both classified as VUS, in a patient with $\mathrm{nCHH}$ with no other phenotypic abnormalities. Both genes have been previously associated with complex phenotypes, so it is unlikely that the variants described here are responsible to this patient's phenotype.

The importance of oligogenic mutations in $\mathrm{CHH}$ has long been recognized (13). It has been suggested that oligogenic inheritance could at least partially explain the phenotypic variability of $\mathrm{CHH}$ within and across families. It is hypothesized that different genetic defects might have a synergistic effect contributing to the phenotype, but in most cases, it is extremely difficult to distinguish whether both variants are sufficient and/ or contributing to the phenotype. In the case of $\mathrm{CHH}$, studying the interaction of these genes indeed increases the comprehension of the wide variability existing in the time of onset of normal puberty and the various forms of presentation of hypogonadotropic hypogonadism, from congenital forms, some reversible to cases of functional hypogonadism. In addition, the concept of oligogenicity may help to elucidate the molecular diagnosis of patients with isolated mutations do not justify the phenotype, such as heterozygous mutations in genes with a typical autosomal recessive inheritance. Oligogenicity was described in $2.5-7 \%$ of the cases in previous studies $(14,15$, 32). With the advent of NGS, the frequency of detection of oligogenicity has recently increased to approximately $15 \%(5,55)$. Here, we identified variants in more than one gene in nine patients, corresponding to $6.9 \%$ of the total cohort. The large number of genes associated with $\mathrm{CHH}$ and the possible influences of the environment on some phenotypes are factors that still make it difficult to prove that multiple genotypes would lead to more severe phenotypes.

The use of targeted NGS in this large cohort provided novel molecular insights in genetic of $\mathrm{CHH}$. Rare and potentially pathogenic variants were identified in more than $30 \%$ of $\mathrm{CHH}$ patients and the vast majority was in genes previously associated with $\mathrm{CHH}$, confirming that the panel is useful in detecting known genes associated with a disease, and for identifying new genes, exomic sequencing certainly is a more appropriate approach. This study was able to amplify the genetic characterization of $\mathrm{CHH}$ and to approximate the proportion of patients with molecular diagnosis of the descriptions in the literature, in addition increasing the identification of the oligogenic cases. However, since the growth of NGS in the approach to many diseases, we must interpret very carefully the results of the large number of variants that will be identified, since even using a strict selection criterion to identify the most relevant findings, after analyzing each variant individually, 51 (66.2\%) of the 77 variants initially identified were considered benign or probably benign.

The complexity of the $\mathrm{CHH}$ genetic model strengthens the importance of the use of new genetics technologies, in the approach of rare diseases and with multiple genetic causes such as $\mathrm{CHH}$. Targeted NGS has been shown to be a powerful tool in molecular diagnosis of this rare condition.

\section{Supplementary data}

This is linked to the online version of the paper at https://doi.org/10.1530/ EJE-18-0764.

\section{Declaration of interest}

The authors declare that there is no conflict of interest that could be perceived as prejudicing the impartiality of this study.

\section{Funding}

This work was supported by Grants 2013/03236-5 (to A A L J) and 2014/50137-5 (SELA - Laboratório de Sequenciamento em Larga Escala) from the São Paulo Research Foundation (FAPESP); Grant 304678/20120 (to A A L J) from the National Council for Scientific and Technological Development (CNPq); grants to A C L (FAPESP 13/03236-5 and CNPq 302849/2015-7).

\section{References}

1 Schwanzel-Fukuda M \& Pfaff DW. Origin of luteinizing hormonereleasing hormone neurons. Nature 1989338 161-164. (https://doi. org/10.1038/338161a0)

2 Wray S. From nose to brain: development of gonadotrophin-releasing hormone-1 neurones. Journal of Neuroendocrinology 201022 743-753. (https://doi.org/10.1111/j.1365-2826.2010.02034.x)

3 Young J, Xu C, Papadakis GE, Acierno JS, Maione L, Hietamäki J, Raivio T \& Pitteloud N. Clinical management of congenital hypogonadotropic hypogonadism. Endocrine Reviews 201940 669-710. (https://doi.org/10.1210/er.2018-00116)

4 Boehm U, Bouloux PM, Dattani MT, de Roux N, Dodé C, Dunkel L, Dwyer AA, Giacobini P, Hardelin JP, Juul A et al. Expert consensus document: European Consensus Statement on congenital hypogonadotropic hypogonadism - pathogenesis, diagnosis and treatment. Nature Reviews: Endocrinology 201511 547-564. (https:// doi.org/10.1038/nrendo.2015.112)

5 Maione L, Dwyer AA, Francou B, Guiochon-Mantel A, Binart N, Bouligand J \& Young J. GENETICS IN ENDOCRINOLOGY: Genetic counseling for congenital hypogonadotropic hypogonadism and Kallmann syndrome: new challenges in the era of oligogenism and next-generation sequencing. European Journal of Endocrinology 2018 178 R55-R80. (https://doi.org/10.1530/EJE-17-0749)

6 Ballabio A \& Camerino G. The gene for X-linked Kallmann syndrome: a human neuronal migration defect. Current Opinion in Genetics and Development 19922 417-421. (https://doi.org/10.1016/ S0959-437X(05)80152-2)

7 de Roux N, Young J, Misrahi M, Genet R, Chanson P, Schaison G \& Milgrom E. A family with hypogonadotropic hypogonadism 
and mutations in the gonadotropin-releasing hormone receptor. New England Journal of Medicine 1997337 1597-1602. (https://doi. org/10.1056/NEJM199711273372205)

8 Mitchell AL, Dwyer A, Pitteloud N \& Quinton R. Genetic basis and variable phenotypic expression of Kallmann syndrome: towards a unifying theory. Trends in Endocrinology and Metabolism 201122 249-258. (https://doi.org/10.1016/j.tem.2011.03.002)

9 Montenegro LR, Silveira LF, Tusset C, de Castro M, Versiani BR, Latronico AC, Mendonca BB \& Trarbach EB. Combined use of multiplex ligation-dependent probe amplification and automatic sequencing for identification of KAL1 defects in patients with Kallmann syndrome. Fertility and Sterility 2013100 854-859. (https:// doi.org/10.1016/j.fertnstert.2013.04.045)

10 Beneduzzi D, Trarbach EB, Min L, Jorge AA, Garmes HM, Renk AC, Fichna M, Fichna P, Arantes KA, Costa EM et al. Role of gonadotropin-releasing hormone receptor mutations in patients with a wide spectrum of pubertal delay. Fertility and Sterility 2014102838. e2-846.e2. (https://doi.org/10.1016/j.fertnstert.2014.05.044)

11 Salenave S, Chanson P, Bry H, Pugeat M, Cabrol S, Carel JC, Murat A, Lecomte P, Brailly S, Hardelin JP et al. Kallmann's syndrome: a comparison of the reproductive phenotypes in men carrying KAL1 and FGFR1/KAL2 mutations. Journal of Clinical Endocrinology and Metabolism 200893 758-763. (https://doi.org/10.1210/jc.2007-1168)

12 Costa-Barbosa FA, Balasubramanian R, Keefe KW, Shaw ND, Al-Tassan N, Plummer L, Dwyer AA, Buck CL, Choi JH, Seminara SB et al. Prioritizing genetic testing in patients with Kallmann syndrome using clinical phenotypes. Journal of Clinical Endocrinology and Metabolism 201398 E943-E953. (https://doi.org/10.1210/jc.2012-4116)

13 Pitteloud N, Quinton R, Pearce S, Raivio T, Acierno J, Dwyer A, Plummer L, Hughes V, Seminara S, Cheng YZ et al. Digenic mutations account for variable phenotypes in idiopathic hypogonadotropic hypogonadism. Journal of Clinical Investigation 2007117 457-463. (https://doi.org/10.1172/JCI29884)

14 Sykiotis GP, Plummer L, Hughes VA, Au M, Durrani S, NayakYoung S, Dwyer AA, Quinton R, Hall JE, Gusella JF et al. Oligogenic basis of isolated gonadotropin-releasing hormone deficiency. PNAS 2010107 15140-15144. (https://doi.org/10.1073/pnas.1009622107)

15 Quaynor SD, Kim HG, Cappello EM, Williams T, Chorich LP, Bick DP, Sherins RJ \& Layman LC. The prevalence of digenic mutations in patients with normosmic hypogonadotropic hypogonadism and Kallmann syndrome. Fertility and Sterility 201196 1424.e6-1430.e6. (https://doi.org/10.1016/j.fertnstert.2011.09.046)

16 Costa EM, Bedecarrats GY, Mendonca BB, Arnhold IJ, Kaiser UB \& Latronico AC. Two novel mutations in the gonadotropin-releasing hormone receptor gene in Brazilian patients with hypogonadotropic hypogonadism and normal olfaction. Journal of Clinical Endocrinology and Metabolism 200186 2680-2686. (https://doi.org/10.1210/ jcem.86.6.7551)

17 Trarbach EB, Costa EM, Versiani B, de Castro M, Baptista MT, Garmes HM, de Mendonca BB \& Latronico AC. Novel fibroblast growth factor receptor 1 mutations in patients with congenital hypogonadotropic hypogonadism with and without anosmia. Journal of Clinical Endocrinology and Metabolism 200691 4006-4012. (https:// doi.org/10.1210/jc.2005-2793)

18 Abreu AP, Trarbach EB, de Castro M, Frade Costa EM, Versiani B, Matias Baptista MT, Garmes HM, Mendonca BB \& Latronico AC. Loss-of-function mutations in the genes encoding prokineticin-2 or prokineticin receptor-2 cause autosomal recessive Kallmann syndrome. Journal of Clinical Endocrinology and Metabolism 200893 4113-4118. (https://doi.org/10.1210/jc.2008-0958)

19 Gianetti E, Tusset C, Noel SD, Au MG, Dwyer AA, Hughes VA, Abreu AP, Carroll J, Trarbach E, Silveira LF et al. TAC3/TACR3 mutations reveal preferential activation of gonadotropin-releasing hormone release by neurokinin B in neonatal life followed by reversal in adulthood. Journal of Clinical Endocrinology and Metabolism 201095 2857-2867. (https://doi.org/10.1210/jc.2009-2320)
20 Teles MG, Trarbach EB, Noel SD, Guerra-Junior G, Jorge A, Beneduzzi D, Bianco SD, Mukherjee A, Baptista MT, Costa EM et al. A novel homozygous splice acceptor site mutation of KISS1R in two siblings with normosmic isolated hypogonadotropic hypogonadism. European Journal of Endocrinology 2010163 29-34. (https://doi. org/10.1530/EJE-10-0012)

21 Trarbach EB, Abreu AP, Silveira LF, Garmes HM, Baptista MT, Teles MG, Costa EM, Mohammadi M, Pitteloud N, Mendonca BB et al. Nonsense mutations in FGF8 gene causing different degrees of human gonadotropin-releasing deficiency. Journal of Clinical Endocrinology and Metabolism 201095 3491-3496. (https://doi. org/10.1210/jc.2010-0176)

22 Silveira LG, Noel SD, Silveira-Neto AP, Abreu AP, Brito VN, Santos MG, Bianco SD, Kuohung W, Xu S, Gryngarten M et al. Mutations of the KISS1 gene in disorders of puberty. Journal of Clinical Endocrinology and Metabolism 201095 2276-2280. (https:// doi.org/10.1210/jc.2009-2421)

23 Trarbach EB, Teles MG, Costa EM, Abreu AP, Garmes HM, Guerra G Jr, Baptista MT, de Castro M, Mendonca BB \& Latronico AC. Screening of autosomal gene deletions in patients with hypogonadotropic hypogonadism using multiplex ligationdependent probe amplification: detection of a hemizygosis for the fibroblast growth factor receptor 1. Clinical Endocrinology $2010 \mathbf{7 2}$ 371-376. (https://doi.org/10.1111/j.1365-2265.2009.03642.x)

24 Doty RL, Shaman P \& Dann M. Development of the University of Pennsylvania Smell Identification Test: a standardized microencapsulated test of olfactory function. Physiology and Behavior 198432 489-502. (https://doi.org/10.1016/0031-9384(84)90269-5)

$25 \mathrm{Li} \mathrm{H}$. Aligning sequence reads, clone sequences and assembly contigs with BWA-MEM. arXiv:1303.39972013 1-3.

26 Tischler G \& Leonard S. Biobambam: tools for read pair collation based algorithms on BAM files. Source Code for Biology and Medicine 2014913.

27 Okonechnikov K, Conesa A \& García-Alcalde F. Qualimap 2: advanced multi-sample quality control for high-throughput sequencing data. Bioinformatics 201632 292-294. (https://doi. org/10.1093/bioinformatics/btv566)

28 Wang K, Li M \& ANNOVAR HH. ANNOVAR: Functional annotation of genetic variants from high-throughput sequencing data. Nucleic Acids Research 201038 e164. (https://doi.org/10.1093/nar/gkq603)

29 Tan A, Abecasis GR \& Kang HM. Unified representation of genetic variants. Bioinformatics 201531 2202-2204. (https://doi.org/10.1093/ bioinformatics/btv112)

30 Naslavsky MS, Yamamoto GL, de Almeida TF, Ezquina SAM, Sunaga DY, Pho N, Bozoklian D, Sandberg TOM, Brito LA, Lazar M et al. Exomic variants of an elderly cohort of Brazilians in the ABraOM database. Human Mutation 201738 751-763. (https://doi. org/10.1002/humu.23220)

31 Richards S, Aziz N, Bale S, Bick D, Das S, Gastier-Foster J, Grody WW, Hegde M, Lyon E, Spector E et al. Standards and guidelines for the interpretation of sequence variants: a joint consensus recommendation of the American College of Medical Genetics and Genomics and the Association for Molecular Pathology. Genetics in Medicine 201517 405-424. (https://doi.org/10.1038/gim.2015.30)

32 Miraoui H, Dwyer AA, Sykiotis GP, Plummer L, Chung W, Feng B, Beenken A, Clarke J, Pers TH, Dworzynski P et al. Mutations in FGF17, IL17RD, DUSP6, SPRY4, and FLRT3 are identified in individuals with congenital hypogonadotropic hypogonadism. American Journal of Human Genetics 201392 725-743. (https://doi. org/10.1016/j.ajhg.2013.04.008)

33 Cassatella D, Howard SR, Acierno JS, Xu C, Papadakis GE, Santoni FA, Dwyer AA, Santini S, Sykiotis GP, Chambion C et al. Congenital hypogonadotropic hypogonadism and constitutional delay of growth and puberty have distinct genetic architectures. European Journal of Endocrinology 2018178 377-388. (https://doi.org/10.1530/ EJE-17-0568) 
34 Bhagavath B, Podolsky RH, Ozata M, Bolu E, Bick DP, Kulharya A, Sherins RJ \& Layman LC. Clinical and molecular characterization of a large sample of patients with hypogonadotropic hypogonadism. Fertility and Sterility 200685 706-713. (https://doi.org/10.1016/j. fertnstert.2005.08.044)

35 Laitinen EM, Vaaralahti K, Tommiska J, Eklund E, Tervaniemi M, Valanne L \& Raivio T. Incidence, phenotypic features and molecular genetics of Kallmann syndrome in Finland. Orphanet Journal of Rare Diseases 20116 41. (https://doi.org/10.1186/1750-1172-6-41)

36 Shaw ND, Seminara SB, Welt CK, Au MG, Plummer L, Hughes VA, Dwyer AA, Martin KA, Quinton R, Mericq V et al. Expanding the phenotype and genotype of female GnRH deficiency. Journal of Clinical Endocrinology and Metabolism 201196 E566-E576. (https:// doi.org/10.1210/jc.2010-2292)

37 Beranova M, Oliveira LM, Bedecarrats GY, Schipani E, Vallejo M, Ammini AC, Quintos JB, Hall JE, Martin KA, Hayes FJ et al. Prevalence, phenotypic spectrum, and modes of inheritance of gonadotropin-releasing hormone receptor mutations in idiopathic hypogonadotropic hypogonadism. Journal of Clinical Endocrinology and Metabolism 200186 1580-1588. (https://doi.org/10.1210/ jcem.86.4.7395)

38 Raivio T, Sidis Y, Plummer L, Chen H, Ma J, Mukherjee A, JacobsonDickman E, Quinton R, Van Vliet G, Lavoie $\mathrm{H}$ et al. Impaired fibroblast growth factor receptor 1 signaling as a cause of normosmic idiopathic hypogonadotropic hypogonadism. Journal of Clinical Endocrinology and Metabolism 200994 4380-4390. (https://doi. org/10.1210/jc.2009-0179)

39 Tommiska J, Känsäkoski J, Christiansen P, Jørgensen N, Lawaetz JG, Juul A \& Raivio T. Genetics of congenital hypogonadotropic hypogonadism in Denmark. European Journal of Medical Genetics 2014 57 345-348. (https://doi.org/10.1016/j.ejmg.2014.04.002)

40 Francou B, Paul C, Amazit L, Cartes A, Bouvattier C, Albarel F, Maiter D, Chanson P, Trabado S, Brailly-Tabard S et al. Prevalence of KISS1 receptor mutations in a series of 603 patients with normosmic congenital hypogonadotrophic hypogonadism and characterization of novel mutations: a single-centre study. Human Reproduction 2016 31 1363-1374. (https://doi.org/10.1093/humrep/dew073)

41 Nie M, Xu H, Chen R, Mao J, Wang X, Xiong S, Zheng J, Yu B, Cui M, Ma W et al. Analysis of genetic and clinical characteristics of a Chinese Kallmann syndrome cohort with ANOS1 mutations. European Journal of Endocrinology 2017177 389-398. (https://doi. org/10.1530/EJE-17-0335)

42 Chan YM, de Guillebon A, Lang-Muritano M, Plummer L, Cerrato F, Tsiaras S, Gaspert A, Lavoie HB, Wu CH, Crowley WF, Jr et al. GNRH1 mutations in patients with idiopathic hypogonadotropic hypogonadism. PNAS 2009106 11703-11708. (https://doi. org/10.1073/pnas.0903449106)

43 Bouligand J, Ghervan C, Tello JA, Brailly-Tabard S, Salenave S, Chanson P, Lombes M, Millar RP, Guiochon-Mantel A \& Young J. Isolated familial hypogonadotropic hypogonadism and a GNRH1 mutation. New England Journal of Medicine $20093602742-2748$. (https://doi.org/10.1056/NEJMoa0900136)

44 Mengen E, Tunc S, Kotan LD, Nalbantoglu O, Demir K, Gurbuz F, Turan I, Seker G, Yuksel B \& Topaloglu AK. Complete idiopathic hypogonadotropic hypogonadism due to homozygous GNRH1 mutations in the mutational hot spots in the region encoding the decapeptide. Hormone Research in Paediatrics 201685 107-111. (https://doi.org/10.1159/000441977)

45 Mason AJ, Hayflick JS, Zoeller RT, Young WS, 3rd, Phillips HS, Nikolics K \& Seeburg PH. A deletion truncating the gonadotropinreleasing hormone gene is responsible for hypogonadism in the hpg mouse. Science 1986234 1366-1371. (https://doi.org/10.1126/ science.3024317)

46 Kim HG, Kurth I, Lan F, Meliciani I, Wenzel W, Eom SH, Kang GB, Rosenberger G, Tekin M, Ozata M et al. Mutations in CHD7, encoding a chromatin-remodeling protein, cause idiopathic hypogonadotropic hypogonadism and Kallmann syndrome. American Journal of Human Genetics $2008 \mathbf{8 3}$ 511-519. (https://doi. org/10.1016/j.ajhg.2008.09.005)

47 Howard SR, Guasti L, Ruiz-Babot G, Mancini A, David A, Storr HL, Metherell LA, Sternberg MJ, Cabrera CP, Warren HR et al. IGSF10 mutations dysregulate gonadotropin-releasing hormone neuronal migration resulting in delayed puberty. EMBO Molecular Medicine 20168 626-642. (https://doi.org/10.15252/emmm.201606250)

48 Sidhoum VF, Chan YM, Lippincott MF, Balasubramanian R, Quinton R, Plummer L, Dwyer A, Pitteloud N, Hayes FJ, Hall JE et al. Reversal and relapse of hypogonadotropic hypogonadism: resilience and fragility of the reproductive neuroendocrine system. Journal of Clinical Endocrinology and Metabolism 201499 861-870. (https://doi. org/10.1210/jc.2013-2809)

49 Dode C, Levilliers J, Dupont JM, De Paepe A, Le Du N, SoussiYanicostas N, Coimbra RS, Delmaghani S, Compain-Nouaille S, Baverel F et al. Loss-of-function mutations in FGFR1 cause autosomal dominant Kallmann syndrome. Nature Genetics 200333 463-465. (https://doi.org/10.1038/ng1122)

50 Falardeau J, Chung WC, Beenken A, Raivio T, Plummer L, Sidis Y, Jacobson-Dickman EE, Eliseenkova AV, Ma J, Dwyer A et al. Decreased FGF8 signaling causes deficiency of gonadotropin-releasing hormone in humans and mice. Journal of Clinical Investigation $2008 \mathbf{1 1 8}$ 2822-2831. (https://doi.org/10.1172/JCI34538)

51 Tornberg J, Sykiotis GP, Keefe K, Plummer L, Hoang X, Hall JE, Quinton R, Seminara SB, Hughes V, Van Vliet G et al. Heparan sulfate 6-O-sulfotransferase 1 , a gene involved in extracellular sugar modifications, is mutated in patients with idiopathic hypogonadotrophic hypogonadism. PNAS 2011108 11524-11529. (https://doi.org/10.1073/pnas.1102284108)

52 Zhu J, Choa RE, Guo MH, Plummer L, Buck C, Palmert MR, Hirschhorn JN, Seminara SB \& Chan YM. A shared genetic basis for self-limited delayed puberty and idiopathic hypogonadotropic hypogonadism. Journal of Clinical Endocrinology and Metabolism 2015 100 E646-E654. (https://doi.org/10.1210/jc.2015-1080)

53 Pingault V, Bodereau V, Baral V, Marcos S, Watanabe Y, Chaoui A, Fouveaut C, Leroy C, Verier-Mine O, Francannet C et al. Loss-offunction mutations in SOX10 cause Kallmann syndrome with deafness. American Journal of Human Genetics 201392 707-724. (https://doi.org/10.1016/j.ajhg.2013.03.024)

54 Diaczok D, Romero C, Zunich J, Marshall I \& Radovick S. A novel dominant negative mutation of OTX2 associated with combined pituitary hormone deficiency. Journal of Clinical Endocrinology and Metabolism 200893 4351-4359. (https://doi.org/10.1210/jc.20081189)

55 Quaynor SD, Bosley ME, Duckworth CG, Porter KR, Kim SH, Kim HG, Chorich LP, Sullivan ME, Choi JH, Cameron RS et al. Targeted next generation sequencing approach identifies eighteen new candidate genes in normosmic hypogonadotropic hypogonadism and Kallmann syndrome. Molecular and Cellular Endocrinology 2016437 86-96. (https://doi.org/10.1016/j.mce.2016.08.007)

56 Legouis R, Hardelin JP, Levilliers J, Claverie JM, Compain S, Wunderle V, Millasseau P, Le Paslier D, Cohen D \& Caterina D. The candidate gene for the X-linked Kallmann syndrome encodes a protein related to adhesion molecules. Cell 1991 67 423-435. (https://doi.org/10.1016/0092-8674(91)90193-3)

57 Topaloglu AK, Reimann F, Guclu M, Yalin AS, Kotan LD, Porter KM, Serin A, Mungan NO, Cook JR, Ozbek MN et al. TAC3 and TACR3 mutations in familial hypogonadotropic hypogonadism reveal a key role for Neurokinin B in the central control of reproduction. Nature Genetics 200941 354-358. (https://doi.org/10.1038/ng.306)

58 Topaloglu AK, Tello JA, Kotan LD, Ozbek MN, Yilmaz MB, Erdogan S, Gurbuz F, Temiz F, Millar RP \& Yuksel B. Inactivating KISS1 mutation and hypogonadotropic hypogonadism. New England Journal of Medicine 2012366 629-635. (https://doi.org/10.1056/ NEJMoa1111184) 
59 de Roux N, Genin E, Carel JC, Matsuda F, Chaussain JL \& Milgrom E. Hypogonadotropic hypogonadism due to loss of function of the KiSS1-derived peptide receptor GPR54. PNAS 2003100 10972-10976. (https://doi.org/10.1073/pnas.1834399100)

60 Seminara SB, Messager S, Chatzidaki EE, Thresher RR, Acierno JS, Jr, Shagoury JK, Bo-Abbas Y, Kuohung W, Schwinof KM, Hendrick AG et al. The GPR54 gene as a regulator of puberty. New England Journal of Medicine 2003349 1614-1627. (https://doi.org/10.1056/ NEJMoa035322)

61 Dode C, Teixeira L, Levilliers J, Fouveaut C, Bouchard P, Kottler ML, Lespinasse J, Lienhardt-Roussie A, Mathieu M, Moerman A et al. Kallmann syndrome: mutations in the genes encoding prokineticin-2 and prokineticin receptor-2. PLoS Genetics 20062 e175. (https://doi. org/10.1371/journal.pgen.0020175)

62 Young J, Metay C, Bouligand J, Tou B, Francou B, Maione L, Tosca L, Sarfati J, Brioude F, Esteva B et al. SEMA3A deletion in a family with Kallmann syndrome validates the role of semaphorin $3 \mathrm{~A}$ in human puberty and olfactory system development. Human Reproduction 2012 27 1460-1465. (https://doi.org/10.1093/humrep/des022)

63 Känsäkoski J, Fagerholm R, Laitinen EM, Vaaralahti K, Hackman P, Pitteloud N, Raivio T \& Tommiska J. Mutation screening of SEMA3A and SEMA7A in patients with congenital hypogonadotropic hypogonadism. Pediatric Research 201475 641-644. (https://doi.org/10.1038/pr.2014.23)

64 Margolin DH, Kousi M, Chan YM, Lim ET, Schmahmann JD, Hadjivassiliou M, Hall JE, Adam I, Dwyer A, Plummer L et al. Ataxia, dementia, and hypogonadotropism caused by disordered ubiquitination. New England Journal of Medicine 2013368 1992-2003. (https://doi.org/10.1056/NEJMoa1215993)

65 Kim HG, Ahn JW, Kurth I, Ullmann R, Kim HT, Kulharya A, Ha KS, Itokawa Y, Meliciani I, Wenzel W et al. WDR11, a WD protein that interacts with transcription factor EMX1, is mutated in idiopathic hypogonadotropic hypogonadism and Kallmann syndrome. American Journal of Human Genetics 201087 465-479. (https://doi. org/10.1016/j.ajhg.2010.08.018)

66 Saitsu H, Osaka H, Sasaki M, Takanashi J, Hamada K, Yamashita A, Shibayama H, Shiina M, Kondo Y, Nishiyama K et al. Mutations in POLR3A and POLR3B encoding RNA polymerase III subunits cause an autosomal-recessive hypomyelinating leukoencephalopathy. American Journal of Human Genetics 201189 644-651. (https://doi. org/10.1016/j.ajhg.2011.10.003)

67 Miura K, Acierno JS, Jr \& Seminara SB. Characterization of the human nasal embryonic LHRH factor gene, NELF, and a mutation screening among 65 patients with idiopathic hypogonadotropic hypogonadism (IHH). Journal of Human Genetics 200449 265-268. (https://doi.org/10.1007/s10038-004-0137-4)

68 Abreu AP, Dauber A, Macedo DB, Noel SD, Brito VN, Gill JC, Cukier P, Thompson IR, Navarro VM, Gagliardi PC et al. Central precocious puberty caused by mutations in the imprinted gene MKRN3. New England Journal of Medicine 2013368 2467-2475. (https://doi. org/10.1056/NEJMoa1302160)

69 Xie H, Cherrington BD, Meadows JD, Witham EA \& Mellon PL. Msx1 homeodomain protein represses the $\alpha \mathrm{GSU}$ and GnRH receptor genes during gonadotrope development. Molecular Endocrinology 201327 422-436. (https://doi.org/10.1210/me.2012-1289)

70 Trarbach EB, Baptista MT, Garmes HM \& Hackel C. Molecular analysis of KAL-1, GnRH-R, NELF and EBF2 genes in a series of Kallmann syndrome and normosmic hypogonadotropic hypogonadism patients. Journal of Endocrinology 2005187 361-368. (https://doi.org/10.1677/joe.1.06103)
71 Pugliese-Pires PN, Fortin JP, Arthur T, Latronico AC, Mendonca BB, Villares SM, Arnhold IJ, Kopin AS \& Jorge AA. Novel inactivating mutations in the GH secretagogue receptor gene in patients with constitutional delay of growth and puberty. European Journal of Endocrinology 2011165 233-241. (https://doi.org/10.1530/EJE-110168)

72 Sun Y, Bak B, Schoenmakers N, van Trotsenburg AS, Oostdijk W, Voshol P, Cambridge E, White JK, le Tissier P, Gharavy SN et al. Loss-of-function mutations in IGSF1 cause an X-linked syndrome of central hypothyroidism and testicular enlargement. Nature Genetics 201244 1375-1381. (https://doi.org/10.1038/ng.2453)

73 Tata B, Huijbregts L, Jacquier S, Csaba Z, Genin E, Meyer V, Leka S, Dupont J, Charles P, Chevenne D et al. Haploinsufficiency of Dmxl2, encoding a synaptic protein, causes infertility associated with a loss of GnRH neurons in mouse. PLoS Biology 201412 e1001952. (https:// doi.org/10.1371/journal.pbio.1001952)

74 Domené HM, Bengolea SV, Martínez AS, Ropelato MG, Pennisi P, Scaglia P, Heinrich JJ \& Jasper HG. Deficiency of the circulating insulin-like growth factor system associated with inactivation of the acid-labile subunit gene. New England Journal of Medicine $2004 \mathbf{3 5 0}$ 570-577. (https://doi.org/10.1056/NEJMoa013100)

75 Topaloglu AK, Lomniczi A, Kretzschmar D, Dissen GA, Kotan LD, McArdle CA, Koc AF, Hamel BC, Guclu M, Papatya ED et al. Loss-offunction mutations in PNPLA6 encoding neuropathy target esterase underlie pubertal failure and neurological deficits in Gordon Holmes syndrome. Journal of Clinical Endocrinology and Metabolism 201499 E2067-E2075. (https://doi.org/10.1210/jc.2014-1836)

76 Riley BM, Mansilla MA, Ma J, Daack-Hirsch S, Maher BS, Raffensperger LM, Russo ET, Vieira AR, Dodé C, Mohammadi M et al. Impaired FGF signaling contributes to cleft lip and palate. PNAS 2007104 4512-4517. (https://doi.org/10.1073/ pnas.0607956104)

77 Jongmans MC, Admiraal RJ, van der Donk KP, Vissers LE, Baas AF, Kapusta L, van Hagen JM, Donnai D, de Ravel TJ, Veltman JA et al. CHARGE syndrome: the phenotypic spectrum of mutations in the CHD7 gene. Journal of Medical Genetics 200643 306-314. (https://doi. org/10.1136/jmg.2005.036061)

78 Bilan F, Legendre M, Charraud V, Manière B, Couet D, GilbertDussardier B \& Kitzis A. Complete screening of 50 patients with CHARGE syndrome for anomalies in the CHD7 gene using a denaturing high-performance liquid chromatography-based protocol: new guidelines and a proposal for routine diagnosis. Journal of Molecular Diagnostics 201214 46-55. (https://doi.org/10.1016/j. jmoldx.2011.08.003)

79 Young J, Bouligand J, Francou B, Raffin-Sanson ML, Gaillez S, Jeanpierre M, Grynberg M, Kamenicky P, Chanson P, Brailly-Tabard S et al. TAC3 and TACR3 defects cause hypothalamic congenital hypogonadotropic hypogonadism in humans. Journal of Clinical Endocrinology and Metabolism 201095 2287-2295. (https://doi. org/10.1210/jc.2009-2600)

80 Dodé C \& Hardelin JP. Kallmann syndrome. European Journal of Human Genetics 200917 139-146. (https://doi.org/10.1038/ ejhg.2008.206)

81 Pitteloud N, Zhang C, Pignatelli D, Li JD, Raivio T, Cole LW, Plummer L, Jacobson-Dickman EE, Mellon PL, Zhou QY et al. Loss-of-function mutation in the prokineticin 2 gene causes Kallmann syndrome and normosmic idiopathic hypogonadotropic hypogonadism. PNAS 2007104 17447-17452. (https://doi. org/10.1073/pnas.0707173104)
Received 17 September 2018

Revised version received 14 May 2019

Accepted 23 May 2019 